UNIVERSIDADE ESTADUAL PAULISTA “JULIO DE MESQUITA FILHO” FACULDADE DE CIÊNCIAS AGRONÔMICAS

CÂMPUS DE BOTUCATU

\title{
SELETIVIDADE DO HERBICIDA TOPRAMEZONE ISOLADO E EM MISTURA EM VARIEDADES DE CANA-DE-AÇÚCAR
}

\section{LEONILDO ALVES CARDOSO}

Tese apresentada à Faculdade de Ciências Agronômicas da UNESP - Campus de Botucatu, para obtenção do título de Doutor em Agronomia (Agricultura).

BOTUCATU-SP

Fevereiro -2010 
UNIVERSIDADE ESTADUAL PAULISTA “JULIO DE MESQUITA FILHO” FACULDADE DE CIÊNCIAS AGRONÔMICAS

CÂMPUS DE BOTUCATU

\section{SELETIVIDADE DO HERBICIDA TOPRAMEZONE ISOLADO E EM MISTURA EM VARIEDADES DE CANA-DE-AÇÚCAR}

\section{LEONILDO ALVES CARDOSO}

Orientador: Prof. Dr. Dagoberto Martins

Tese apresentada à Faculdade de Ciências Agronômicas da UNESP - Campus de Botucatu, para obtenção do título de Doutor em Agronomia (Agricultura).

BOTUCATU-SP

Fevereiro - 2010 
FICHA CATALOGRÁFICA ELABORADA PELA SEÇÃO TÉCNICA DE AQUISIÇÃO E TRATAMENTO DA INFORMAÇÃO - SERVIÇO TÉCNICO DE BIBLIOTECA E DOCUMENTAÇÃ̃O - UNESP - FCA - LAGEADO - BOTUCATU (SP)

Cardoso, Leonildo Alves, 1976-
Seletividade do herbicida Topramezone isolado e em mis-
tura em variedades de cana-de-açúcar / Leonildo Alves Car-
doso. - Botucatu : [s.n.], 2010.
v, 58 f. : gráfs., tabs., fots. color.
Tese (Doutorado) - Universidade Estadual Paulista, Fa-
culdade de Ciências Agronômicas, Botucatu, 2010
Orientador: Dagoberto Martins
Inclui bibliografia.
1. Saccharum ssp. 2. Topramezone. 3. Tebuthiuron. 4.
Ametryn. I. Martins, Dagoberto. II. Universidade Estadual
Paulista "Júlio de Mesquita Filho" (Campus de Botucatu).
Faculdade de Ciências Agronômicas. III. Título.


UNIVERSIDADE ESTADUAL PAULISTA "JÚLIO DE MESQUTTA FILHO" FACULDADE DE CIÊNCIAS AGRONÔMICAS

CAMPUS DE BOTUCATU

CERTIFICADO DE APROVAÇ̃o

TITULO: SELETIVIDADE DO HERBICIDA TOPRAMEZONE ISOLADO B BM MISTURA EM VARIEDADES DE CANA-DE-ACUCAR"

ALUNO LEONILDO ALVES CARDOSO

ORIENTADOR: PROF. DR DAGOBERTO MARTINS

Aprovado pela Comissâo Examinadora

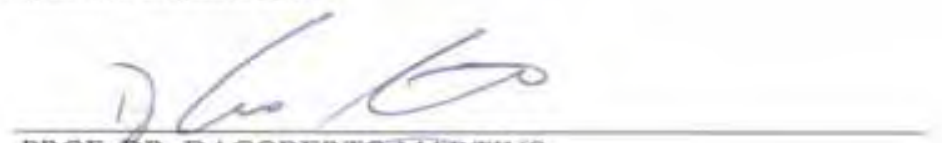

PRQE DR, DAGOBERTOMARTINS

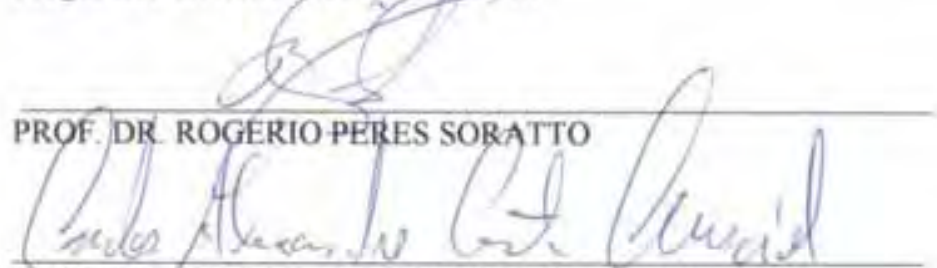

PROF DR CARLOS ALEXANDRE COSTA CRUSCIOL

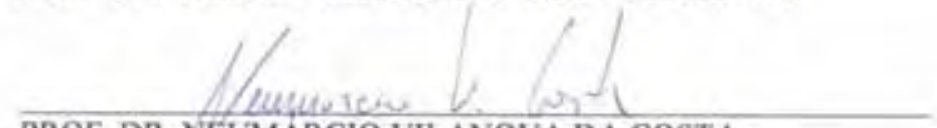

PROF. DR. NEUMARCIO VILANOVA DA COSTA

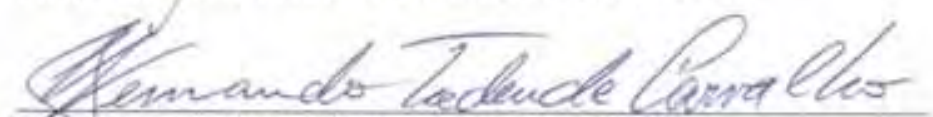

PROF. DR. FERNANDO TADEU DE CARVALHO

Data đa Realizaçâo: 23 de fevereim 2010. 


\section{A toda minha família,}

pelo apoio e confiança acreditando sempre que o estudo

é uma das maiores e melhores formas de prosperar mesmo que em condições adversas!

Amo muito vocês!

\section{DEDICO}

Aos meus pais João Alves Cardoso e

Adélia Pereira Cardoso pelo exemplo de vida!

Vocês são exemplos de Fé e Amor no decorrer de minha vida.

OFEREÇO 


\section{AGRADECIMENTOS}

A Deus, pelo dom da vida.

Ao Prof. Dr. Dagoberto Martins, pela valiosa amizade, pelo companheirismo, pela orientação segura, paciência e ajuda pessoal que muito contribuíram para minha formação profissional.

À Universidade Estadual Paulista "Julio de Mesquita e Filho" - Faculdade de Ciências Agronômicas de Botucatu, pela oportunidade de realização do curso.

A todos os professores da FCA em especial aos do Departamento de Produção Vegetal - Setor Agricultura pelos ensinamentos, amizade e excelente convivência.

A insubstituível família do Núcleo de Pesquisas Avançadas em Matologia "NUPAM" Andréia Cristina, Neumárcio Vilanova, Sergio Ricota, José Iran, Renata Marques, Maria Renata, Caio Ferraz, Saulo Ítalo, Guilherme Sasso e Hermerson pelas valiosas e indispensáveis colaborações no desenvolvimento deste ensaio.

Aos amigos de matologia Eduardo Negrisoli, Marcelo Correia, Beto, China e Guilherme, pela amizade.

Aos amigos de sempre Ferdinando Eunuco, Rodolfo Pinhal, Ângela Cerkete, Haroldo Tio, Renaki, Marcão, Marcelo Rigotti, Rômulo Kaled, Rafael, Simerio, Carla, Gabi, e Anne, pela amizade durante esta etapa da vida;

Aos Funcionários do Departamento de Produção Vegetal - Agricultura e as funcionarias da Seção de Pós-Graduação pela amizade e profissionalismo. 
À CNPq, pela bolsa de estudos concedida.

À Usina da Barra / Grupo Cosan, especialmente aos Srs. Sebastião Ribeiro e Biega, pela disponibilidade da colheita e realizações de analises tecnológicos.

A todos os colegas e amigos (as) da Pós-Graduação minha imensa gratidão pelos momentos de convivência tão agradáveis e importantes.

A todas as pessoas que direta ou indiretamente, contribuíram na realização deste estudo. 


\section{ÍNDICE}

1. RESUMO

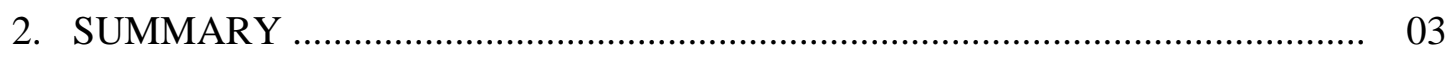

3. INTRODUÇÃ

4. REVISÃO DE LITERATURA …............................................................ 08

5. MATERIAL E MÉTODOS ….................................................................. 18

5.1 Instalação e condução do experimento....................................................... 18

5.2 Delineamento experimental............................................................ 20

5.3 Aplicaçãa de herbicidas...................................................................... 21

5.4 Características avaliadas................................................................... 22

5.4.1 Avaliação visual de fitotoxicidade................................................. 22

5.4.2 Número de perfílhos............................................................... 22

5.4.3 Altura de plantas.................................................................. 23

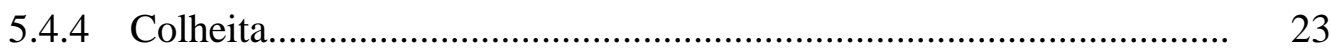

5.4.5 Comprimento e diâmetro de colmos................................................... 23

5.4.6 Características tecnológicas .......................................................... 23

5.4.7 Produtividade agrícola............................................................... 24

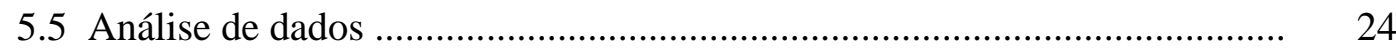

6. RESULTADOS E DISCUSSÃO................................................................. 25

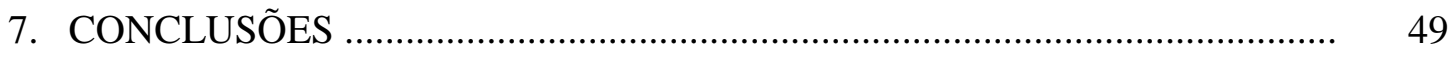

8. REFERÊNCIAS BIBLIOGRÁFICAS …..................................................... $\quad 50$ 


\section{RESUMO}

Este trabalho teve como objetivo avaliar a seletividade do herbicida topramezone aplicado de forma isolado e em mistura com tebuthiuron, em pós-emergência inicial sobre dez variedades de cana-de-açúcar em condição de cana-planta. O experimento foi conduzido na Fazenda Experimental Lageado, pertencente a FCA/UNESP - Botucatu/SP. Os tratamentos utilizados foram: topramezone + Dash $\left(70 \mathrm{~g} \mathrm{ha}^{-1}+0,25 \% \mathrm{v} / \mathrm{v}^{-1}\right)$; topramezone + tebuthiuron + Dash $\left(70+1000 \mathrm{~g} \mathrm{ha}^{-1}+0,25 \% \mathrm{v} / \mathrm{v}^{-1}\right)$; topramezone + tebuthiuron + Dash $(100$ $\left.+1000 \mathrm{~g} \mathrm{ha}^{-1}+0,25 \% \mathrm{v} / \mathrm{v}^{-1}\right)$ e ametryn + tebuthiuron $\left(1500+1000 \mathrm{~g} \mathrm{ha}^{-1}\right)$, aplicados aos 35 DAP (dias após o plantio), além de uma testemunha sem aplicação. O delineamento experimental utilizado foi o de blocos casualizados em parcelas subdivididas com quatro repetições. As dez variedades utilizadas foram: SP 83 2847, SP 80 3280, RB 85 5453, SP 80 1842, SP 89 1115, RB 86 7515, PO 8862, RB 85 5156, SP 801816 e SP 81 3250. Para aplicação dos herbicidas, utilizou-se um pulverizador costal, pressurizado a $\mathrm{CO}_{2}$ e equipado com barra de aplicação com seis pontas Teejet XR 110 02VS, e um volume de aplicação foi de $200 \mathrm{~L} \mathrm{ha}^{-1}$. As avaliações visuais de fitotoxicidade foram realizadas aos 7, 14, 28 e 35 dias 
após a aplicação (DAA), sendo que aos 28, 64 e 300 DAA dos herbicidas foram determinados os números de perfilhos por metro e aos 28 e 64 DAA determinou-se a altura média de 15 plantas nas duas linhas centrais da parcela. Ao final do estudo foram determinados os parâmetros tecnológicos como pol, fibra e brix e, os parâmetros produtivos como o comprimento, diâmetro e peso dos colmos e a produção de açúcar por parcela. A formulação isolada de topramezone seguida de suas misturas com tebuthiuron proporcionaram inicialmente severos sintomas visuais de injúrias às plantas de cana-de-açúcar; contudo as plantas de todas as variedades testadas tiveram uma total recuperação visual a partir dos 35 dias após a aplicação dos herbicidas. A mistura de tebuthiuron com topramezone reduziu os sintomas de injurias provocados pelo topramezone. A mistura entre ametryn + tebuthiuron foi o tratamento que evidenciou a ação fitotóxica menos severa às plantas, independente da variedade estudada. Nenhum dos herbicidas testados afetou negativamente os componentes tecnológicos e produtivos das variedades estudadas, no qual, as diferenças observadas foram dependentes apenas das variedades, sendo assim, pode-se considerar seletivos os herbicidas utilizados sobre as dez variedades de cana-de-açúcar utilizadas.

Palavras-chave: Cana-de-açúcar, topramezone, tebuthiuron e ametryn. 
SELECTIVITY OF TOPRAMEZONE HERBICIDE ALONE AND MIXTURE ON VARIETIES OF SUGAR CANE. Botucatu, 2010. 58p. Tese (Doutorado em Agronomia /Agricultura) - Faculdade de Ciências Agronômicas, Universidade Estadual Paulista "Julio de Mesquita Filho".

\section{Author: LEONILDO ALVES CARDOSO}

Adviser: DAGOBERTO MARTINS

\section{SUMMARY}

The objective of this experiment was to evaluate the selectivity topramezone herbicide alone, and in a mixture with tebuthiuron. The herbicides were applied after sprouting to ten varieties of sugar cane on condition of first crop. This research was carried out on the Experimental field from São Paulo State University in Botucatu/SP city. The treatments were: topramezone + Dash $\left(70 \mathrm{~g} \mathrm{ha}^{-1}+0.25 \% \mathrm{v} / \mathrm{v}^{-1}\right)$; topramezone + tebuthiuron + Dash $\left(70+1000 \mathrm{~g} \mathrm{ha}^{-1}+0.25 \% \mathrm{v} / \mathrm{v}^{-1}\right)$; topramezone + tebuthiuron + Dash $(100$ $\left.+1000 \mathrm{~g} \mathrm{ha}^{-1}+0.25 \% \mathrm{v} / \mathrm{v}^{-1}\right)$ and ametryne + tebuthiuron $\left(1500+1000 \mathrm{~g} \mathrm{ha}^{-1}\right)$ applied 30 DAP (days after planting). Treatments were organized in a randomized complete block split plot with 4 replications for each treatment. Ten varieties utilized in this study: SP 83 2847, SP 80 3280, RB 85 5453, SP 80 1842, SP 89 1115, RB 86 7515, PO 8862, RB 85 5156, SP 80 1816, and SP 81 3250. The herbicides treatments were applied using a $\mathrm{CO}_{2}$ pressurized backpack sprayer at 2.0 bar. The boom was equipped with six TeeJet XR 110 02VS flat fan nozzles, delivering a volume of $200 \mathrm{~L} \mathrm{ha}^{-1}$. Visual fitotoxicity evaluations were taken 7, 14, 28, and 35 DAA (days after application). At 28, 64, and 300 DAA the number of tillers per meter were 
determined, and at 28 and 64 DAA average plant height was determined from 15 plants in two central lines of each plot. At the end of the study, technological parameters such as pol, fiber, and brix were determined. At this same stage, productive parameters such as length, diameter, stalk weight, and sugar production per plot were also determined. The formulation of topramezone alone followed its mixtures with tebuthiuron initially provided severe visual injury to the sugar cane plants, however the plants of all varieties tested had a total visual injury recovery after 35 days after herbicide application. The mixture with tebuthiuron reduced the symptoms of injuries caused by topramezone. The mixture of ametryn + tebuthiuron was the treatment that showed a less severe action phytotoxic to plants, regardless of the variety studied. Herbicides tested, no negative effects on the technological nor productive components of the studied varieties were observed. The herbicides utilized on the ten varieties of sugar cane can therefore be considered selective.

Keywords: Sugar cane, topramezone, tebuthiuron and ametryn 


\section{INTRODUÇÃO}

A cana-de-açúcar (Saccharum officinarum L.) é uma espécie originária da Ásia, que adaptou-se as condições brasileiras, tornando-se uma das culturas de maior importância econômica para o Brasil, produzindo matéria-prima para a indústria sucroalcoleira e co-geração de energia elétrica. A partir da década de 1970, esta cultura tornou-se progressivamente mais importante para o país à medida que o setor da agroindústria brasileira foi solicitado a contribuir para a solução da emergente crise energética, face a sua potencialidade de produzir energia de forma renovável.

Dentre os problemas existentes no setor canavieiro, e que oneram a produção, destaca-se o controle das plantas daninhas, responsável por até $80 \%$ das perdas na produção, sendo que aumenta o custo de produção em cerca de $30 \%$ para cana-soca e de 15 a 20\% para cana planta, além de diminuir o número de cortes viáveis (LORENZI, 1988, 1995, BARROS \& LEONEL, 2001; AZÂNIA, 2004, PROCOPIO et al., 2004). 
Nas condições do Brasil, dentre os métodos empregados no manejo de plantas daninhas, o controle químico é o mais utilizado nesta cultura, sendo o consumo de herbicida elevado, principalmente em razão da grande extensão das áreas plantadas, o que constitui um atraente mercado, alvo de grandes investimentos na produção de herbicidas com potencial de uso nestas áreas.

Tanto para a cana-de-açúcar, como para qualquer outra espécie cultivada, a recomendação de um herbicida está condicionada a sua seletividade, ou seja, a sua capacidade de eliminar espécies vegetais indesejáveis sem promover reduções economicamente significativas, tanto na qualidade quanto na quantidade produzida pela cultura Velini et al. (2000). Ainda, de acordo com autor, não basta um herbicida simplesmente ser seletivo para uma determinada espécie, o mesmo deve ser seletivo também para as cultivares mais comuns da mesma e, especificamente para cana-de-açúcar, uma cultura semiperene, por vários ciclos produtivos.

O contínuo desenvolvimento de novos herbicidas para uso nesta cultura, bem como a dinâmica de introdução ou troca de variedades, faz com que, o estudo da interação destes dois fatores torne-se constante. De acordo com Fagliari et al. (2001), a seletividade de novos herbicidas deve ser avaliada nas cultivares de cana-de-açúcar mais plantadas, assim como a tolerância de variedades recém lançadas aos herbicidas tradicionalmente utilizados nesta cultura também deve ser investigada. Na prática, estas avaliações são realistas em estudos específicos sobre seletividade, com metodologia própria para cana-de-açúcar, e sempre sem a presença da comunidade infestante.

A ausência de injúrias visuais nas plantas tratadas com um determinado herbicida, também não é suficiente para determinar a sua tolerância a este produto, sendo necessário para tal, uma avaliação mais detalhada na quantidade e qualidade do seu produto final. Especificamente, para a cana-de-açúcar, os parâmetros produtivos normalmente avaliados são o comprimento, número e peso de colmos, enquanto que a qualidade pode ser analisada mensurando os teores de pol, brix e fibra, além de quantificar a produção de açúcar.

Dentre os herbicidas utilizados na cultura da cana-de-açúcar, o tebuthiuron (N\{5-(1,1-dimetiletil)-1,3,4-tiadiazol-2-il\}-n,n'- dimetiluréia) é um herbicida seletivo e registrado com o nome comercial de Combine 500 SC. Deve ser aplicado em pré- 
emergência das plantas daninhas anuais e em pós-emergência da cana-de-açúcar, desde que esta não interfira na perfeita distribuição do herbicida no solo. $\mathrm{O}$ produto possui amplo espectro de controle, sendo eficiente no controle de diversas plantas daninhas de grande importância para a cultura da cana-de-açúcar. As doses variam de 1,6 a 2,4 $\mathrm{L} \mathrm{ha}^{-1}$ em função das características físicas do solo e a única aplicação pode manter a cultura no limpo até o fechamento (RODRIGUES e ALMEIDA, 2005). Ele pertencente ao grupo químico dos derivados da uréia e, portanto, age pela inibição do fotossistema II.

O herbicida topramezone [3-(4,5-dihydro-isoxazol-3-yl)-4methanesulfonyl-2-methyl-phenyl] é um novo herbicida de aplicação em pós-emergência com amplo espectro de controle de gramíneas e latifoliadas na cultura do milho (GROSSMANN \& EHRHARDT, 2007). Ele pertence o grupo químico das pyrazolones ou benzoil pyrazoles, bloqueia a formação de homogentisate, possivelmente através da inibição da 4hidroxifenilpiruvato dioxigenase (4-HPPD), resultando na inibição da síntese de carotenóides e conseqüente degradação da clorofila, provocando a clorose e a necrose nas folhas de plantas susceptíveis (ANONYMOUS, 2006). O rápido metabolismo combinado com a menor sensibilidade da enzima alvo "4-HPPD”, contribui para a tolerância do milho a este herbicida. Por ser seletivo a cultura do milho e apresentar alta eficiência no controle de plantas daninhas, especula-se que também pode ser utilizado de forma seletiva para a cultura de cana-de-açúcar.

Desta forma, o objetivo deste estudo foi avaliar a seletividade do herbicida topramezone isolado e em mistura com tebuthiuron em variedades de cana-deaçúcar em condição de cana-planta. 


\section{REVISÃO DE LITERATURA}

A cana-de-açúcar teve sua origem provavelmente na nova Guine, sendo levada para a Índia, de onde tem-se o mais antigo registro de sua existência. De acordo com Agrianual (1997), ela foi introduzida no Brasil no século XVI, trazida da Ilha da Madeira, sendo seu ciclo iniciado quase simultaneamente em Pernambuco e São Paulo. Os primeiros engenhos foram construídos próximos de Santos/SP. Durante 150 anos, a cana-de-açúcar foi o principal produto agrícola brasileiro não extrativista, cujo ciclo foi interrompido com a descoberta do ouro e diamantes em Minas Gerais. A importância da cana-de-açúcar começou a diminuir durante o final do século XVIII, quando os Holandeses passaram a cultivá-la e a construir engenhos em suas colônias no Caribe. Com o declínio da mineração do ouro no começo do século XIX, renasceu o interesse pela cultura. Atualmente, destaca-se entre as mais importantes culturas no cenário nacional, produzindo matéria-prima para a indústria sucroalcooleira e co-geração de energia elétrica. 
A partir da década de 1970, a cultura da cana-de-açúcar foi se tornando mais importante para o país à medida que o setor da agroindústria brasileira foi solicitado a contribuir para a solução da emergente crise energética, face a sua potencialidade de produzir energia a partir de uma fonte renovável (KUVA, 1999; AZANIA, 2004 E CORREA, 2006).

Nos últimos anos, a área produtiva, bem como a produtividade total, tem aumentado continuamente, devido, principalmente, as boas perspectivas do mercado futuro. O Brasil é o maior produtor mundial de cana-de-açúcar, produzindo 547 milhões de toneladas de colmos em uma área aproximadamente 6,9 milhões de hectares. Em relação ao total da produção e área colhida no país, o Estado de São Paulo ocupa um lugar de destaque, com percentuais de 59 e 53\%, respectivamente. O crescimento do setor sucroalcooleiro é importante para a economia do país, pois implica na geração de empregos e energia renovável nacional. Conforme dados de (AGRIANUAL, 2008), a produção de açúcar na safra 2007/2008 foi estimada em cerca de 30 milhões de toneladas e a de álcool, principalmente anidro, em 21,3 bilhões de litros. A agroindústria da cana-de-açúcar gera ao Brasil cerca de um milhão de empregos diretos e de 3 a 5 milhões de indiretos. Somente no Estado de São Paulo o setor canavieiro responde por $40 \%$ do emprego rural e $35 \%$ da renda agrícola. (CARVALHO, 1998).

O plantio e a colheita da cana-de-açúcar são rotinas agrícolas realizadas praticamente o ano todo nas diferentes regiões produtoras do país, as quais apresentam características edafo-climáticas muito diferentes umas das outras. Essa situação conflitante tem apresentado como um grande desafio para o técnico responsável pelos tratos culturais, principalmente na recomendação de estratégias de manejo de plantas daninhas.

O controle de plantas daninhas destaca-se como o que mais oneram dentre os problemas existentes no setor canavieiro, responsável por até $80 \%$ das perdas na produção (BARROS \& LEONEL, 2001; AZANIA, 2004). A interferência negativa resultante da presença das plantas daninhas nas áreas agrícolas produtoras de cana-de-açúcar podem causar sérios problemas como reduções na quantidade e qualidade do produto colhido, decréscimos no número de cortes viáveis e aumentos nos custos de produção em cerca de $30 \%$ para cana-soca e de 15 a 20\% para cana-planta (LORENZI, 1995). As plantas daninhas competem com a cultura por água, nutrientes e radiação solar, podendo também liberar substâncias com efeitos alelopáticos (FAY \& DUKE, 1977), afetando direta ou indiretamente 
a germinação, crescimento e desenvolvimento das plantas cultivadas, além de atuar como hospedeira de pragas e doenças (PITELLI, 1985).

A intensidade de interferência entre uma cultura agrícola e comunidade infestante depende de (i) fatores ligados à própria cultura, como a variedade, espaçamento e densidade de plantio, (ii) fatores ligados a comunidade infestante, como composição específica, densidade e distribuição dos indivíduos na lavoura e (iii) da época e extensão do período em que a cultura e a comunidade infestante estiveram em convivência. Além disso, a interação lavoura e comunidade infestante pode ser influenciada por condições edafo-climáticas locais e pelas práticas culturais empregadas no preparo e manejo do solo e da cultura em si (PITELLI, 1985). De maneira geral, pode-se dizer que, quanto maior for o período de convivência múltipla - comunidade infestante e cultura - maior será o grau de interferência Hernandez et al. (2001).

A cana-de-açúcar apesar de ser altamente eficiente na utilização de recursos disponíveis para o seu crescimento e desenvolvimento é afetada nas fases iniciais de crescimento, pelas plantas daninhas, que em muitos casos utilizam os mesmos recursos, de forma eficiente (NEGRISOLI, 2002 e PROCÓPIO et al., 2003).

Diversos trabalhos de pesquisa indicam períodos do ciclo da cultura em que a competição acarreta perdas na produção da cana-de-açúcar. No entanto, não se pode extrapolar esses resultados para todas as condições, pois esses períodos são influenciados por diversos fatores, como época de plantio e de brotação da cana soca (condições climáticas), variedades, qualidade da muda, espécie de plantas daninhas, adubação, profundidade de plantio, espaçamento, ou seja, fatores que aceleram ou retardam o desenvolvimento da canade-açúcar Procópio et al. (2003). Geralmente, cultivares de rápido crescimento inicial e alta capacidade de sombreamento de solo são menos afetadas pela interferência das plantas daninhas.

Conforme relato de Arevalo (1997), estima-se que cerca de 1000 espécies de plantas daninhas co-habitem o agroecossistema da cana-de-açúcar, nas distintas áreas de produção no mundo. Em condições brasileiras, algumas espécies podem ser consideradas mais importantes, tanto no decorrer quanto na colheita, afetando a produtividade da cultura, a saber: Brachiaria decumbens, B. plantaginea, B. mutica, Digitaria horizontalis, D. nuda, D. ciliaris, Cenchrus echinatus, Eleusine indica, Panicum maximum, Cynodon 
dactilon, Ipomoea grandifolia, I. nil, I. quamoclit, Merremia cissoides, Amaranthus sp., Bidens pilosa, Euphorbia heterophylla, Commelina sp., Richardia brasiliensis, Sida sp., Cyperus rotundus, Acanthospermum hispidum e Altenanthera tenella etc., de acordo com estudos realizados por Arevaldo et al. (1998), Velini \& Martins (1998), Martins et al. (1999), Velini et al. (2000), Kuva et al. (2001), Azania et al. (2002), Dias et al. (2003), Kuva et al. (2003), Correia \& Durigan (2004), Christoffoleti et al. (2005) e . Oliveira \& Freitas (2008). Dentre estes estudos, o de Pedrinho Junior \& Durigan (2001), relataram que o capim colonião (Panicum maximum) e capim-braquiária (B. decumbens) merecem destaque, haja visto que muitos canaviais encontram-se atualmente em áreas de antigas pastagens degradadas, formadas principalmente por estas espécies. Kuva (1999), relatou que a infestação de $P$. maximum em cana-de-açúcar pode acarretar em redução superior a 50\% na produtividade. Em um estudo realizado por Kuva et al. (2001), observaram que esta redução de produtividade provocada pela intensa interferência de B. decumbens foi de $82 \%$.

Os efeitos negativos causados pela presença das plantas daninhas podem ser minimizados por práticas de controle ao alcance dos produtores, como métodos mecânicos, culturais e químicos. Na condição de produção atual no Brasil, o método químico é o mais utilizado e o que apresenta melhor alternativa para os produtores (PEDRINHO JR. \& DURIGAN, 2001 e ROSSI, 2004), em razão da extensão das áreas cultivadas, dificuldades de controle das plantas daninhas, escassez de mão-de-obra, facilidade de aplicação, eficácia dos herbicidas e baixos custos.

Segundo Deuber (1997), a cana-de-açúcar apresenta-se como a segunda cultura em consumo de herbicida no país. Almeida \& Rodrigues (2005), por sua vez, descrevem 41 moléculas herbicidas registradas para essa cultura.

O uso de herbicidas na cultura da cana-de-açúcar também é elevado em outros países. Leibbrandt (1995), cita o desenvolvimento de três novos herbicidas para esta cultura na África do Sul. Mason (1991), descreve o uso de atrazine, metribuzim, tebuthiuron, diuron e 2,4 D nas lavouras de cana-de-açúcar em Trinidad Tobago. Millhollon \& Benda (1999), citam o uso de metribuzin em Louisiana E.UA.

Apesar da grande diversidade de herbicida existente para o controle de plantas daninhas na cultura de cana-de-açúcar, Arevaldo et al. (1998) comentam que ainda não existe um produto ideal que seja seletivo a todas as cultivares de cana-de-açúcar; que 
apresente eficiência em todas as condições ambientais e que não afete o ambiente quando utilizado incorretamente.

Dentre as características ideais de um herbicida, Oliveira Jr. \& Constantin (2001), destacam que a seletividade é a base para o sucesso do controle químico de plantas daninhas na produção agrícola, sendo considerada como uma medida da resposta diferencial de diversas espécies de plantas a um determinado herbicida. Como exemplo desta resposta diferencial em culturas, pode ser citado o trabalho de Vargas \& Fleck (1999) no qual fica explícito que o herbicida diclofop-metyl a $540 \mathrm{~g} \mathrm{ha}^{-1}$ promoveu redução no rendimento de grão de aveia-preta, enquanto que na cultura do trigo não foi observado nenhum efeito negativo. Pode-se citar ainda, o herbicida metribuzin que é recomendado para cana-de-açúcar em uma dose quatro vezes maior do que para batata (ALMEIDA \& RODRIGUES, 1998).

Furuhashi et al. (2000), avaliou a fitointoxicação causada por flazasulfurom em três variedades de cana-de-açúcar : SP 79 1011, RB 855536 e RB 835486 , concluíram que a variedade RB 835486 foi a que apresentou maior sensibilidade ao tratamento químico, enquanto que as variedades SP 79 1011, RB 855536 apresentaram sintomas dentro da normalidade. Também o Rolim et al. (2000), avaliaram a tolerância de seis variedades de cana-de-açúcar a alguns herbicidas aplicados em pré-emergência, de forma isolada e em misturas com as variações de doses, em um solo arenoso. Estes pesquisadores observaram as diferenças do grau de sensibilidade entre as variedades.

Azania et al. (2005 e 2006), testaram a seletividade dos herbicidas diuron + hexazinone, ezafenidin + hexazinone, metribuzin e isoxaflutole, aplicados em pósemergência inicial e tardia as plantas da cultivar RB 83 5089, na época das chuvas em soqueira do terceiro corte. Concluíram que, os herbicidas foram mais fitotóxicos quando aplicados em pós-emergência tardia e que todos prejudicaram a produtividade, características tecnológicas e rendimento de açúcar, exceto o diuron + haxazinone para as características tecnológicas e o rendimento de açúcar. Entretanto, utilizando os mesmos tratamentos quimicos sobre a soqueira do quarto ano durante o período de estiagem, eles concluíram que os herbicidas diuron + hexazinone, ezafenidin + hexazinone e isoxaflutole aplicados em pósemergência tardia prejudicaram a produtividade. Azania et al. (2006).

De forma mais simplificada, Velini et al. (2000) define como seletividade a capacidade de um herbicida em eliminar plantas daninhas de uma cultura sem 
reduzir-lhe a produtividade. Acredita-se que este conceito de seletividade seja mais adequado, pois o termo cultura é mais abrangente, podendo referir-se aos diversos cultivares de uma espécie. Rolim \& Christoffoleti (1984), afirmam que as diversas variedades de cana-de-açúcar testadas apresentam características morfológicas e fisiológicas diferentes, sendo provável que ocorram alterações de comportamento quanto a sua tolerância a herbicidas específicos. Arevaldo et al. (1998), por sua vez, destacam que podem ocorrer cultivares de cana-de-açúcar suscetíveis, tolerantes e resistentes a um determinado ingrediente ativo, tendo esta classificação como resultado da interação diferenciada de cada cultivar com o herbicida. Desta forma, fica evidente que a seletividade não se deve restringir ao nível de espécie na cultura da cana-de-açúcar, na qual o número de cultivares é elevado.

A literatura cita um número elevado de estudos de eficiência de herbicidas no controle de plantas daninhas na cultura da cana-de-açúcar. De maneira geral, na condução deste tipo de estudo, os pesquisadores avaliam também seletividade do produto testado. Especificamente sobre seletividade, existe um número menor de trabalhos publicados. Deve-se destacar, ainda, que na maioria dos trabalhos conduzidos tanto sobre a eficiência de controle de plantas daninhas, como especificadamente sobre seletividade, é comum a utilização de pelo menos um herbicida de uso tradicional na cana-de-açúcar como tratamento padrão (TERRA, 2003).

Cruz \& Leiderman (1978), avaliando a eficiência dos herbicidas oxidiazon, napropamide, methazole e A-3587 em fase experimental de desenvolvimento, para o controle de plantas daninhas na cana-de-açúcar, determinaram o efeito destes produtos sobre o número e peso de colmos da variedade CB 41-76. Concluíram que nenhum dos herbicidas testados influenciou negativamente estes parâmetros produtivos. Estes pesquisadores utilizaram atrazine e 2,4 D como tratamento padrão e obtiveram a mesma conclusão para estes herbicidas.

Clement et al. (1979), além da eficiência no controle de plantas daninhas, avaliou também o efeito do herbicida hexazinone, isoladamente e de sua mistura com diuron nos parâmetros tecnológicos e na produção de colmos da variedade CB 45/3 em condição de cana-planta, não foi constatado nenhum efeito negativo dos herbicidas testados sobre estes parâmetros avaliados. Cruz \& Gurgel (1983), por sua vez, avaliando a eficiência destes mesmos produtos no controle de capim-colchão na cana-de-açúcar, também estudaram 
a sua seletividade sobre os parâmetros tecnológicos e peso de colmos da variedade NA 56-79, chegando as mesmas conclusões.

Mascarenhas et al. (1995), avaliaram a eficiência do herbicida halosulforun e de um padrão, 2,4 D, no controle de tiririca, em cana-de-açúcar. Os pesquisadores avaliaram ainda a quantidade de injúria promovida por estes herbicidas à cultura, além de determinar o número de plantas, folhas e perfilhos aos 120 e 210 DAP (dias após o plantio) e, a altura de plantas aos 120, 150, 180 e 210 DAP da variedade RB 72454 . Visualmente, nenhum dos herbicidas proporcionou qualquer sintoma de injúrias às plantas e também não afetaram negativamente nenhum outro parâmetro avaliado, porém não determinaram o rendimento de colmos e produção de açúcar.

Silva et al. (1996) avaliou a eficiência de diferentes doses de flazasulfuron aplicado de forma isolada e em mistura com diuron e ametryne, no controle de C. rotundus e a sua seletividade para a variedade de cana-de-açúcar CB - 45/3. Concluíram que o flazasulfuron aplicado isoladamente foi seletivo para este cultivar, no entanto, sua mistura, tanto com diuron quanto com a ametryn, afetou negativamente o perfilhamento aos 120 dias após a aplicação dos tratamentos. Esta redução também foi observada nos tratamentos com diuron e ametryn aplicados de forma isolada.

Da mesma forma, Constantin et al. (1996), avaliaram a eficiência do herbicida isuron no controle de plantas daninhas da cana-de-açúcar e sua seletividade a variedade RB 72 454, em condição de cana-planta; comparado com herbicidas tradicionalmente utilizados nesta cultura, como: diuron, ametryn, tebuthiurom, clomazone e com as misturas de diurom + hexazinone e ametyn + diuron; apesar de realizar apenas avaliações visuais de intoxicação, estes autores concluíram que nenhum dos herbicidas testados, influenciaram de forma negativa o desenvolvimento da cultura.

Edward \& Richard Jr. (1997), avaliaram a eficiência de diversos herbicidas no controle de Sorgum halepense, em cana-de-açúcar; para tal, utilizaram sulfometuron em diversas doses, metribuzin, terbacil, atrazine, trifuralin, pendimethalim, pendimethalim + atrazine e seqüencial de trifuralim com atrazine, aplicados sobre as variedades CP 65-357 e CP 70-321; avaliaram, ainda, o efeito dos herbicidas sobre o peso de colmos e produção de açúcar destas variedades. Concluíram que todos os tratamentos utilizados foram seletivos as cultivares testadas. 
Maciel et al. (2008), determinaram a eficiência e seletividade dos herbicidas trifloxysulfuron-sodium + ametryn e hexazinone + diuron em função da tecnologia de aplicação e do manejo mecânico da palha. Obtiveram um eficiente controle químico, acima de $91 \%$ das espécies $D$. horizontalis (6 folhas ate 1 e 2 perfilhos) e B. Decumbens (6 a 8 folhas) no qual, no final do ensaio, não observaram diferenças significativas entre os tratamentos utilizados sobre os parâmetros analisados da variedade SP $80 \quad 1842$ (fitotoxicidade, altura, numero de perfílhos e diametros de colmos).

Em estudos específicos sobre seletividade, Rolim \& Christoffoleti (1984), avaliaram a tolerância das variedades CB 41-76, NA 56-79, e IAC 52-510 a quatro doses do herbicida tebuthiuron aplicado em cana-planta. Visualmente a variedade CB 41-76 apresentou-se mais sensível ao herbicida tebuthiuron, quando comparado com as demais, entretanto, o rendimento agrícola e o teor de pol das variedades não foram afetados negativamente por nenhuma das doses testadas.

Negrisoli et al. (2004) avaliando seletividade de herbicidas tebuthiuron, ametryn, sulfentrazone, metribuzim, izoxaflutole, clomazone, oxyfruorfen e azafenidinthexazinone aplicados em doses representativas das comercialmente utilizadas em pré-emergência. Concluíram que todos os herbicidas utilizados, mostraram-se seletivos a variedade RB 85 5113, não afetando seu crescimento, sua produtividade e suas caracteristicas tecnológicas. Resultados semelhantes foram observados por Barela \& Christofoleti (2006), utilizando a variedade RB 86 7515, também relataram que apesar de sintomas iniciais de injúrias promovidos por estes herbicidas, no final do estudo, todos mostraram-se seletivos, não ocasionaram em perdas significativas de rendimento ou da qualidade de colmos.

Millhollon \& Fanguy (1989) avaliaram a sensibilidade das variedades de cana-de-açúcar CP 65 357, CP 70 321, CP 72 356, CP 72 370, CP 73351 e CP 74383 aos herbicidas asulam a 3,7 e 6,7 $\mathrm{kg} \mathrm{ha}^{-1}$, dalapon a 5,0 $\mathrm{kg} \mathrm{ha}^{-1}$ e MSMA a 4,5 $\mathrm{kg} \mathrm{ha}^{-1}$. Observaram que a variedade CP 72370 teve seu rendimento reduzido quando tratada com a maior dose de asulam. Já as variedades CP 70321 e CP 72356 apresentaram maiores fitointoxicações visuais promovidas pelo herbicida dalapon, porém não tiveram sua produtividade afetada. Da mesma forma, o herbicida MSMA promoveu sintomas visuais de intoxicação a todas as variedades, entretanto, estas recuperaram-se e não ocorreram reflexos negativos na produção. 
O herbicida clomazone aplicado em pós-emergência nas doses de 0,55; 1,$10 ; 1,65$ e 2,2 $\mathrm{kg} \mathrm{ha}^{-1}$ sobre a soqueira de variedade SP 71 1406, promoveu redução no teor de clorofila e altura de plantas, independente da dose utilizada, porém o perfilhamento, a produção final de colmos, o teor de pol e quantidade de açúcar produzida não foram influenciados negativamente por este herbicida Velini et al. (1993).

Constantin (1996) avaliou a sensibilidade das variedades RB 83 5089, RB 83 5486, SP 79 1011, RB 785148 e RB 72454 ao herbicida halosulfuron na dose de 112,5 $\mathrm{g} \mathrm{ha}^{-1}$ e conclui que todas as variedades testadas foram tolerantes a este herbicida.

Durigan et al. (2005), avaliando a seletividade de herbicida flazasulfuron isolado e em mistura com adjuvante aterbane, aplicados em pós-emergência inicial (três folha) e tarda (de cinco a seis folhas) na variedade RB 845257 em dois tipos de solos (solo arenoso e solo argiloso). Concluíram que, nenhum tratamento afetou negativamente a produção, apesar do estádio tardia de plantas cultivadas em solo arenoso proporcionarem maiores sintomas iniciais de fitotoxicidade.

Lourenzi et al. (1994), testou a seletividade do herbicida oxifluorfen aplicado em duas doses sobre a variedade SP 71 6163, em cana-planta de dezoito meses; além deste herbicida os pesquisadores utilizaram ainda uma mistura de ametryn + diurom em duas concentrações como tratamentos padrões. Visualmente esta variedade foi mais sensível ao herbicida oxifluorfen do que aos demais, porém a altura de plantas, o teor de pol e o rendimento de colmos não foram afetados negativamente por nenhum dos herbicidas testados. Comprovado o efeito seletivo de herbicida oxifluorfen aplicado de forma isolada, Velini et al. (2000) avaliou a sua seletividade em mistura com ametryn aplicados em pré e pós-emergência sobre diversas variedades de cana-de-açúcar. Estes pesquisadores também não observaram efeito negativo dos tratamentos testados.

Azania et al. (2001), estudou o efeito de diversas doses do herbicida imazapic na variedade RB 835059 em condição de cana-soca de segundo ano e constatou que os sintomas visuais de fitotoxicidade foram leves e não afetaram as características produtivas e tecnológicas desta variedade. Neste trabalho os autores utilizaram ainda o herbicida tebuthiuron a $1100 \mathrm{~g} \mathrm{ha}^{-1}$ como tratamento padrão, sendo também seletivo a esta cultivar de cana-de-açúcar. 
A descoberta de novas moléculas e o uso generalizado dos herbicidas tem contribuído para a produção de cana-de-açúcar em maior quantidade e melhor qualidade, além de facilitar práticas culturais e reduzir o aparecimento de pragas e doenças Lorenzi et al. (1994).

Observa-se que existem diversos trabalhos testando a seletividade dos herbicidas tradicionalmente utilizados na cana-de-açúcar, bem como a tolerância das principais cultivares desta espécie a estes defensivos. Desta forma, sendo o topramezone isolado e em mistura com tebuthiuron de uso recente nesta cultura, faz-se necessário avaliar o efeito seletivo destes produtos sobre as principais variedades da mesma, pois não se encontrou na literatura nenhum trabalho com a cultura da cana-de-açúcar. 


\section{MATERIAL E MÉTODOS}

\subsection{Instalação e condução do experimento}

O experimento foi conduzido na Fazenda Experimental Lageado, pertencente à Faculdade de Ciências Agronômicas da Universidade Estadual Paulista "Julio de Mesquita Filho" FCA/UNESP - Botucatu / SP, em um solo classificado como Nitossolo Vermelho Estruturado (Embrapa, 1999), cuja características químicas e físicas encontram-se nas Tabelas 1 e 2, respectivamente.

Tabela 1. Caracterização química do solo da área experimental Botucatu-SP/2007.

\begin{tabular}{ccccccccccc}
\hline $\begin{array}{c}\mathrm{pH} \\
\mathrm{CaCl}_{2}\end{array}$ & $\begin{array}{c}\text { M.O. } \\
\mathrm{G} \mathrm{dm}^{-3}\end{array}$ & $\begin{array}{c}\mathrm{P}_{\text {resina }} \\
\mathrm{Mg} \mathrm{dm}^{-3}\end{array}$ & $\mathrm{Al}^{3+}$ & $\mathrm{H}+\mathrm{Al}$ & $\mathrm{K}$ & $\mathrm{Ca}$ & $\mathrm{Mg}$ & $\mathrm{SB}$ & $\mathrm{CTC}$ & $\mathrm{V} \%$ \\
\hline 5,3 & 12 & 10 & 0 & 22 & 0,7 & 22 & 5 & 28 & 50 & 56 \\
\hline
\end{tabular}


Tabela 2. Caracterização física do solo da área experimental Botucatu-SP/2007

\begin{tabular}{ccc}
\hline Areia (\%) & Silte (\%) & Argila (\%) \\
\hline 57 & 18 & 25 \\
\hline
\end{tabular}

Os dados diários referentes às médias de temperaturas e precipitação pluvial durante a condução do experimento coletados na Estação Meteorológica da FCA estão apresentados na Figura 1.

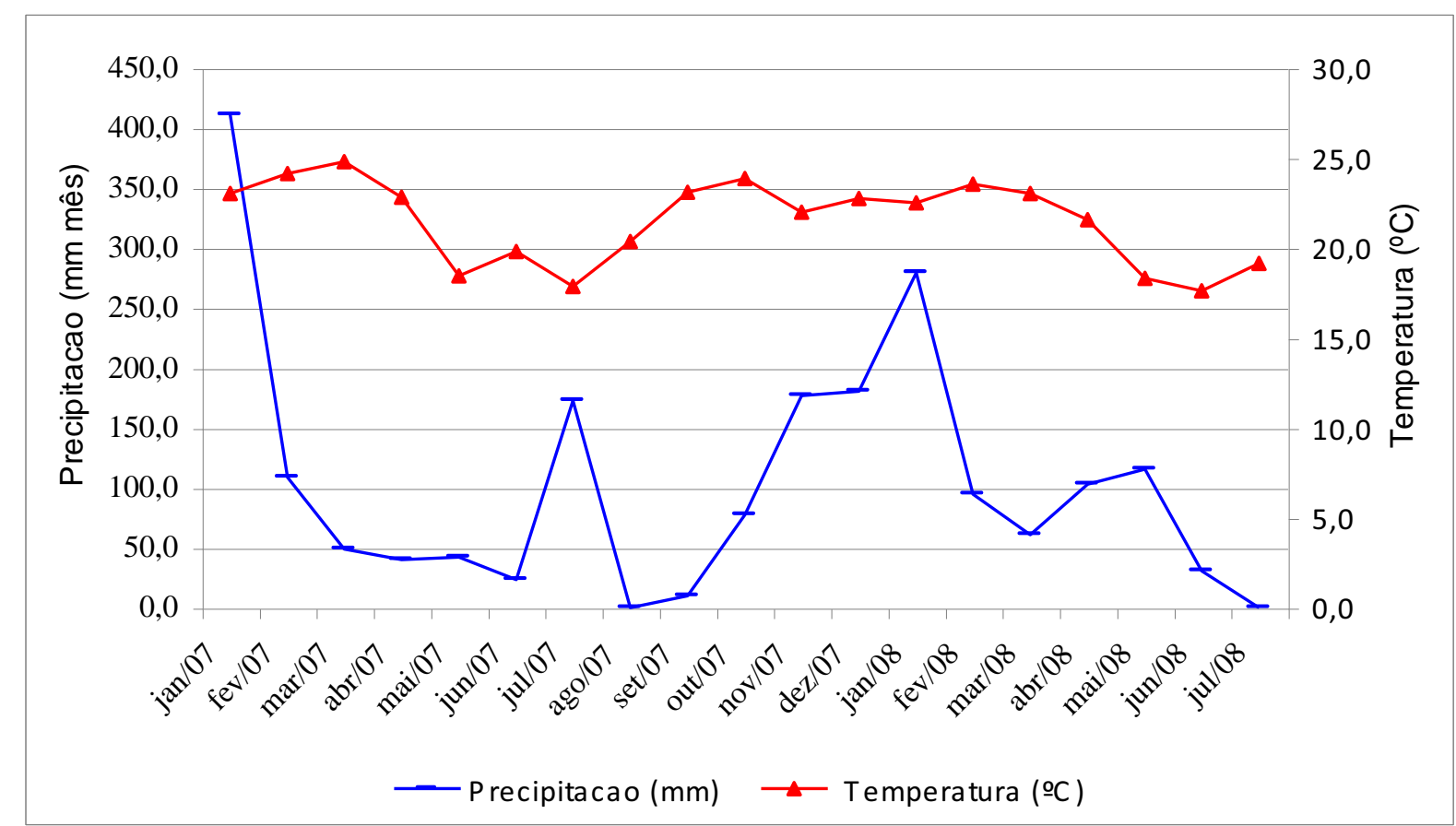

Figura 1. Valores de precipitação $\left(\mathrm{mm} \mathrm{dia}^{-1}\right)$ e medias de temperaturas $\left({ }^{\circ} \mathrm{C}\right)$ registradas durante a condução do experimento. Botucatu/SP 2007/08.

Realizou-se em 08/02/2007 o plantio de dez variedades de cana-deaçúcar, sendo estas: SP 83 2847, SP 80 3280, RB 85 5453, SP 80 1842, SP 89 1115, RB 86 7515, PO 8862, RB 85 5156, SP 801816 e SP 813250.

$\mathrm{Na}$ distribuição das mudas no sulco de plantio espaçado a 1,40 m entre a linha, adotou-se o sistema de colmos cruzados "pé e ponta", procurando atingir a média de 12 gemas por metro (Figura 2). No momento do plantio, adubou-se a área com $600 \mathrm{~kg} \mathrm{ha}^{-1} \mathrm{de}$ 
adubo da formulação 08-28-16, sendo o mesmo distribuído em área total, após 20 dias da realização da calagem. A adução de cobertura foi realizada aos 64 dias após o plantio, utilizando-se $350 \mathrm{~kg} \mathrm{ha}^{-1}$ da fórmula 20-05-20, depositado ao lado da linha de plantio e incorporado manualmente.

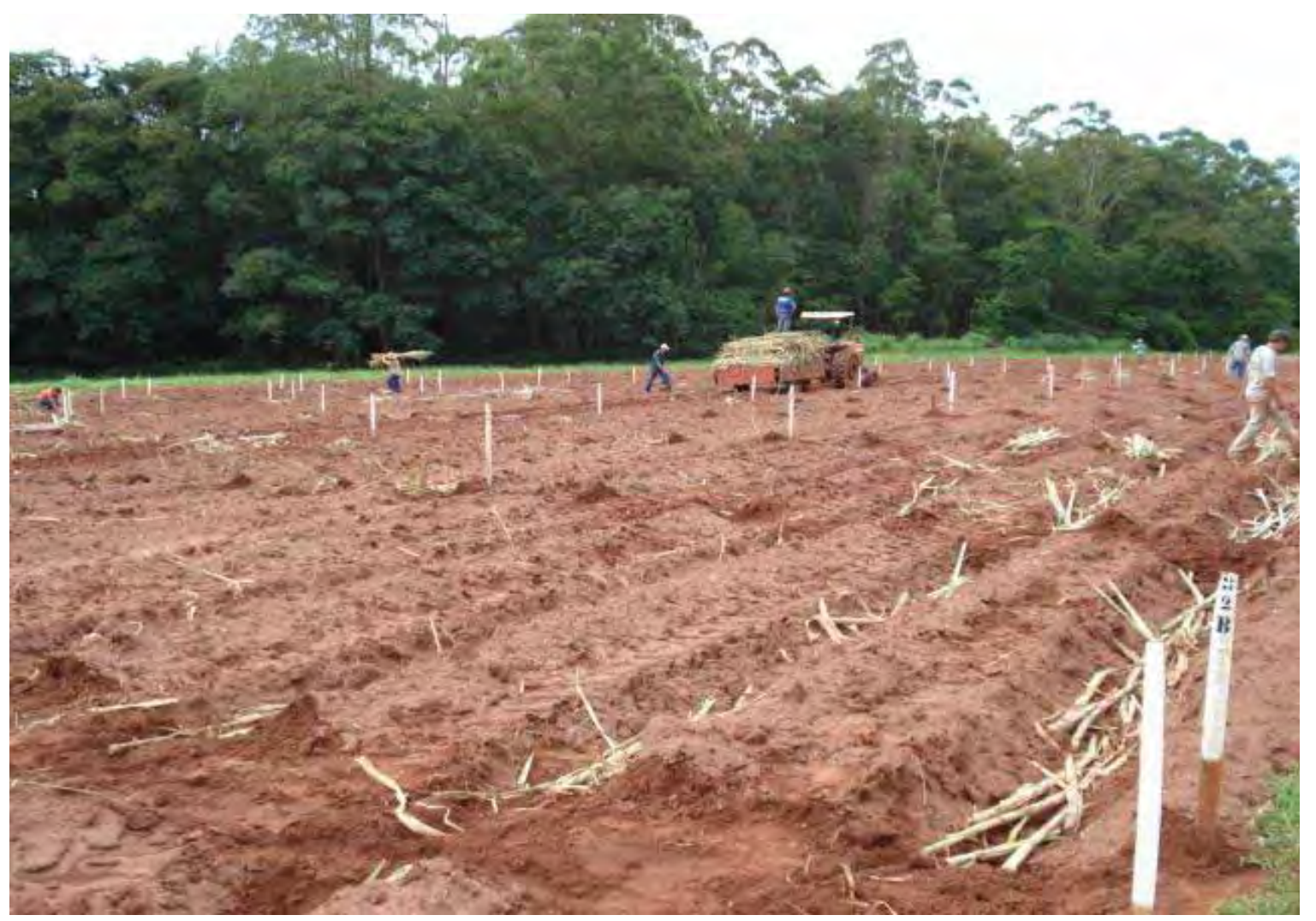

Figura 2. Vista geral da distribuição dos colmos de cana-de-açúcar na área experimental. Botucatu/SP, 2007.

\subsection{Delineamento experimental}

Foi utilizado o delineamento experimental em blocos ao acaso em parcelas subdivididas, com quatro repetições. As variedades foram dispostas nas parcelas e os tratamentos herbicidas nas subparcelas. Cada parcela foi constituída de 5 subparcelas, sendo cada uma composta de $6 \mathrm{~m}$ de comprimento por 5,6 m de largura $\left(33,6 \mathrm{~m}^{2} /\right.$ parcela $)$. 


\subsection{Aplicação dos herbicidas}

Os herbicidas foram aplicados aos 35 DAP (dias após o plantio) e, no momento da aplicação, as plantas estavam com 2 a 4 folhas (Figura 3). Os tratamentos estão descritos na Tabela 3.

Tabela 3. Tratamentos utilizados no experimento. Botucatu/SP, 2007/08.

\begin{tabular}{lc}
\hline Tratamentos & $\begin{array}{c}\text { Dose } \\
(\mathbf{g ~ h a}\end{array}$ \\
\hline 1. testemunha & --- \\
2. topramezone + Dash & $70+0,25 \% \mathrm{v} / \mathrm{v}^{-1}$ \\
3. topramezone + tebuthiuron + Dash & $70+1000+0,25 \% \mathrm{v} / \mathrm{v}^{-1}$ \\
4. topramezone + tebuthiuron + Dash & $100+1000+0,25 \% \mathrm{v} / \mathrm{v}^{-1}$ \\
5. ametryn + tebuthiuron & $1500+1000$ \\
\hline
\end{tabular}

topramezone utilizou-se o produto comercial BAS 670

tebuthiuron utilizou-se o produto comercial, Combine $500 \mathrm{SC}\left(500 \mathrm{~g} \mathrm{~L}^{-1}\right)$

ametryn utilizou-se o produto comercial, Herbipac $500 \mathrm{BR}\left(500 \mathrm{~g} \mathrm{~L}^{-1}\right)$

adicionou-se $\left(0,25 \%\right.$ de $\left.\mathrm{v} / \mathrm{v}^{-1}\right)$ do adjuvante Dash nos tratamentos contendo topramezone

A aplicação dos herbicidas foi realizada em 15/03/2007 e as condições do clima apresentavam temperatura do ar de $27{ }^{\circ} \mathrm{C}$, umidade relativa do ar de $65 \%$ e velocidade de vento de 2 a $4 \mathrm{~km} \mathrm{~h}^{-1}$. O equipamento utilizado na aplicação dos tratamentos foi um pulverizador costal, pressurizado a $\mathrm{CO}_{2}$ e equipado com barra de aplicação com seis pontas Teejet XR 110 02VS. Utilizou-se o volume de aplicação de $200 \mathrm{~L} \mathrm{ha}^{-1}$. 


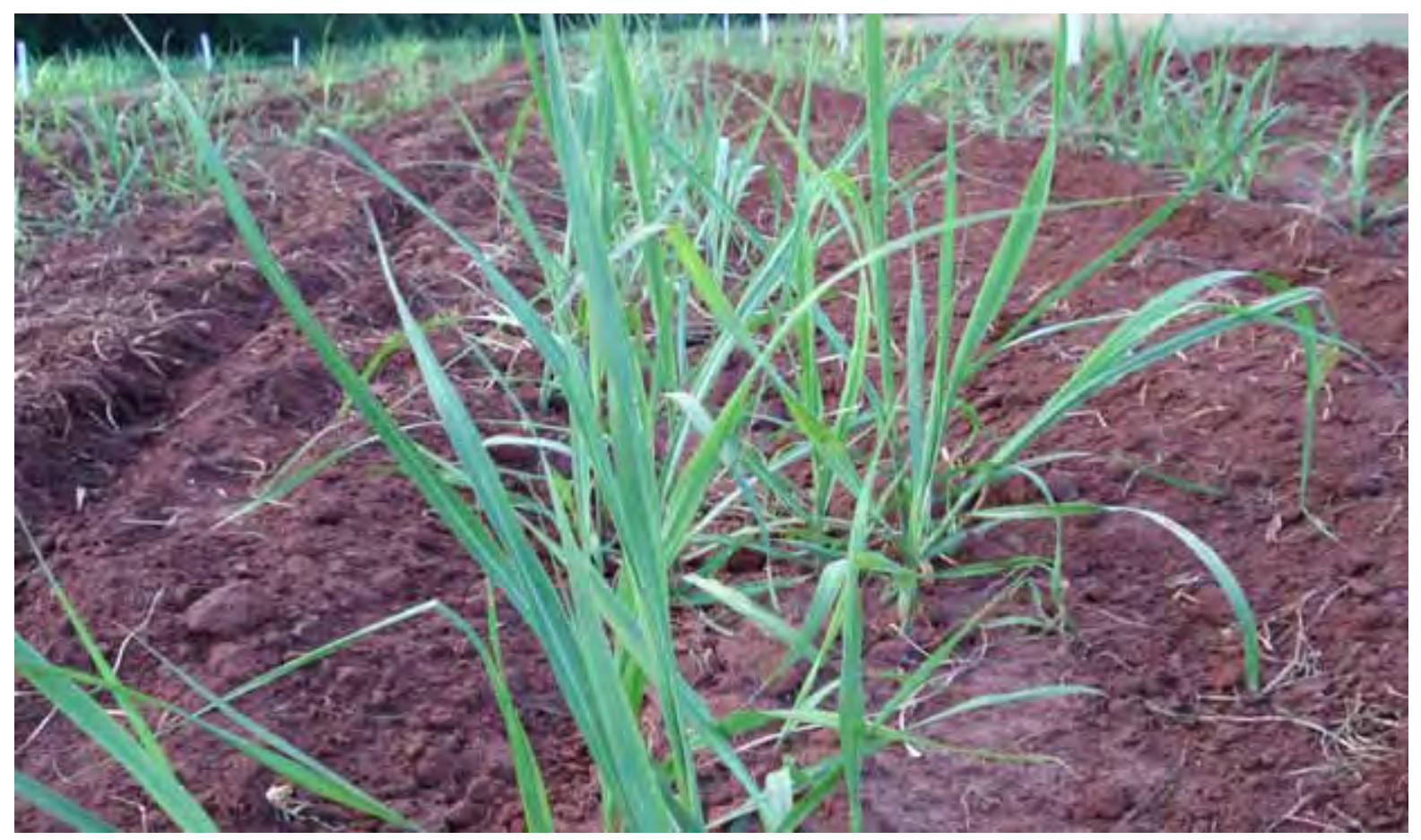

Figura 3. As plantas de cana-de-açúcar com 2 a 4 folhas no momento da aplicação dos herbicidas. Botucatu/SP, 2007.

\subsection{Características avaliadas}

5.4.1 Avaliação visual de fitointoxicação das plantas: as avaliações visuais de fitotoxicidade foram realizadas aos 7, 14, 28 e 35 dias após a aplicação (DAA) dos herbicidas, por meio de uma escala percentual de notas, no qual "zero" correspondeu a nenhuma injúria e "cem" a morte das plantas.

5.4.2 Número de perfílhos: os números de perfílhos foram determinados aos 28 e 64 dias após a aplicação dos herbicidas nas duas linhas centrais de cada parcela. Já, aos 300 DAA foram contados os números de colmos industrializáveis, também nas duas linhas centrais. 
5.4.3 Altura de plantas: a altura de plantas foi determinada por meio de medição com régua graduada em centímetros, da distância entre o solo até a ponta da folha de planta escolhida, selecionando aleatoriamente 15 plantas nas duas linhas centrais da parcela.

5.4.4 Colheita: os colmos de cada parcela foram colhidos no dia 30/07/2008, pelo método manual, com queima, sendo que a queima foi realizada aproximadamente 14 horas antes do início do corte.

5.4.5 Comprimento e diâmetro dos colmos: após o corte, foram escolhidos aleatoriamente 20 colmos por parcela para a determinação do comprimento e diâmetro. Para a realização desta operação foram formadas 5 equipes com 4 componentes. Cada equipe utilizou-se uma fita métrica de 500 centímetros e um paquímetro graduado a $12 \mathrm{~cm}$ de diâmetro. Duas pessoas realizaram as medições de comprimento, uma realizou a medição de diâmetro enquanto a ultima anotou os valores, sendo que no momento da medição, a fita foi disposta sobre o colmo de forma a acompanhar as curvas apresentadas pelos mesmos, e para a medição do diâmetro, estabeleceu-se região basal do colmo, nomeadamente no $3^{\circ}$ nó nas mesmas plantas utilizadas para a avaliação de comprimento.

5.4.6 Características tecnológicas: por ocasião da colheita, foram retiradas amostras de 10 colmos por parcelas que foram desintegrados e homogeneizados, no qual uma alíquota de $500 \mathrm{~g}$ foi submetida à prensa hidráulica para a determinação do teor de Pol, Brix e fibra. Todos os colmos foram submetidos aos despontes na altura da gema apical (ponto de quebra), encaminhado para o "Laboratório de Pureza de Cana" da Unidade de produção do Grupo COSAN - Unidade Barra, para serem processados conforme CONSECANA (2006).

a) Pol\% cana (PC): foi calculada através da seguinte expressão: $\mathrm{PC}=\mathrm{S} \times(1-0,01 \mathrm{~F}) \times \mathrm{C}$, onde:

$\mathrm{S}=$ Pol do Caldo extraído

$\mathrm{F}=$ Fibra industrial $\%$ cana

$\mathrm{C}=$ fator de transformação da pol do caldo extraído em pol do caldo absoluto.

b) Brix \% caldo: determinado por refratometria a $20^{\circ} \mathrm{C}$ (SCHENEIDER, 1979). 
c) Fibra \% cana: determinado segundo Fernandes (2000) através da fórmula: Fpcts $=(0,08 \times$ PBU $)+0,876$, onde: PBU = Peso úmido (grama) do bagaço da prensa (resíduo da prensagem de $500 \mathrm{~g}$ de cana).

d) Produção de açúcar $\left(\mathrm{t} \mathrm{ha}^{-1}\right)$ foi determinada a partir do cálculo [(TCH x \%pol) / 100], onde :

$$
\mathrm{TCH}=\text { refere-se à produtividade da cana-de-açúcar em } \mathrm{t} \mathrm{ha}^{-1} \text {. }
$$

5.4.7 Produtividade agrícola $(\mathbf{T C H})$ : para o cálculo da produtividade agrícola pesou-se todos os colmos colhidos por parcela $\left(36,6 \mathrm{~m}^{2}\right)$, extrapolando-os para a obtenção da produtividade em toneladas por hectare $\left(\mathrm{t} \mathrm{ha}^{-1}\right)$. Para tal, utilizou-se uma máquina carregadora adaptada para este trabalho. No qual, a garra desta máquina era acionada hidraulicamente, sendo presa por cabos de aço ao braço de comando; sendo que no cabo principal, entre o braço e a garra, encontrava-se um dinamômetro digital com capacidade para dois mil quilos. No momento do corte, foi propositalmente dividida em duas bandeiras (montes) por parcela, o que facilitou a pesagem, uma vez que cada bandeira coube perfeitamente na garra da maquina.

\subsection{Análise dos dados}

Os resultados obtidos foram submetidos á analise de variância pelo teste $\mathbf{F}$, e as medias dos tratamentos comparados pelo teste de Tukey a $5 \%$ de probabilidade. 


\section{RESULTADOS E DISCUSSÃO}

Na Tabela 4 estão apresentadas as porcentagens de fitointoxicação visual das dez variedades de cana-de-açúcar avaliadas em diferentes períodos de tempo após a aplicação de diversos herbicidas em pós-emergência inicial da cultura da cana-de-açúcar. Observou-se que aos 7 dias após a aplicação (DAA), que todos os tratamentos químicos, de uma forma geral, proporcionaram a todas as variedades de cana-de-açúcar uma fitointoxicação visual de intensidade vairavel, dependendo da variedade e tratamento químico ocorreu desde cloroses à necroses. Grossmann \& Ehrhardt (2007), Maciel et al. (2008) e Terra (2003), descreveram esses sintomas de injúrias como amarelecimento do limbo foliar, seguido pela requeima das folhas, começando pelo ápice e pelas laterais e estendendo-se para a nervura central, ocorrendo, em alguns casos, secamento total das folhas. Nota-se que os maiores sintomas de injúrias foram observados nos tratamentos contendo o herbicida topramezone, principalmente o tratamento isolado $\left(70 \mathrm{~g} \mathrm{ha}^{-1}\right)$ e a maior dose de mistura entre topramezone + tebuthiuron $\left(100 \mathrm{~g} \mathrm{ha}^{-1}+1000 \mathrm{~g} \mathrm{ha}^{-1}\right)$, no qual, em algumas variedades, como PO 8862 e SP 
813250 os níveis de injúrias chegaram a serem preocupantes ultrapassando os 30\%, superiores ao limite máximo de $27 \%$ estabelecido por Veline et al. (1993) para que não ocorram reduções das características produtivas da cana-de-açúcar. Ressalta-se que a mistura de tebuthiuron ao topramezone reduziu as injúrias provocadas por este último herbicida em todas as variedades estudadas.

As variações de injúrias observadas nas cultivares submetidas aos mesmos tratamentos químicos, evidenciaram a existência de características intrínseca das variedades quanto a tolerância a herbicida. Ainda, ficou evidente, supor que a grande intoxicação visual promovida pela mistura de tebuthiuron com o topramezone, tenham ocorrido mais em função do topramezone do que em função de tebuthiuron. Além dos sintomas serem atípicos do topramezone, conforme a descrição do (GROSSMANN \& EHRHARDT, 2007) em estudo do mecanismo de ação do topramezone e a sua seletividade a cultura do milho, observa-se que o tratamento padrão utilizado neste estudo (ametryn + tebuthiuron) proporcionaram apenas leves sintomas de injúrias sobre as plantas.

Aos 14 DAA, constatou-se, de uma forma geral, reduções progressivas dos sintomas iniciais de injúrias observados em todas as variedades de cana-de-açúcar, exceto para a variedade RB 867515 tratadas com a dose isolada de topramezone e a maior dose da mistura de topramezone + tebuthiuron, com aumento dos sintomas fitotoxicidade de 26,2 para $31,3 \%$ e de 25,5 para $36,3 \%$, respectivamente, no qual o nível de sintomas é considerado elevado (Velini et al 1993). Entretanto, mistura entre tebuthiuron + ametryn (1000 $\mathrm{g} \mathrm{ha}^{-1}+$ $1500 \mathrm{~g}$ ha 1 ), foi o tratamento que menos proporcionou sintomas visuais de injúrias às plantas de cana-de-açúcar, variando de 5 a 10\%, exceto a variedade PO 8862, no qual a injúria atingiu $20 \%$, valor intermediário, aceitável agronomicamente.

Aos 28 DAA, os sintomas visuais de fitotoxicidade haviam quase desaparecidos em todas as variedades de cana-de-açúcar, independente do tratamento químico testado, exceto nas variedades RB 86 7515, PO 8862 e SP 80 1816, nos quais, alguns tratamentos contendo o herbicida topramezone ainda continuavam com os sintomas fitotóxicos considerados como intermediarias, variando de 11 e 15,5\%. As variações observadas, demonstraram que as variedades de cana-de-açúcar podem apresentar padrões diferenciados de crescimento e superação da intoxicação e que este padrão de recuperação pouco depende da intensidade inicial de intoxicação. 
Ressalta-se, ainda, que a redução acentuada das notas de fitotoxicidade foi devido a ausência de fitotoxicidade nas folhas novas e não a redução da área das lesões, ou seja, os sintomas mantiveram-se restritos aos pontos de contato dos herbicidas com as folhas mais velhas, sendo que este fato indicou que absorção radicular não teve importância em termos de intoxicação das plantas. Observações semelhantes feitas por Azania (2001) e Terra (2002), em estudos de seletividades de herbicidas em diferentes variedades de cana-de-açúcar , no qual, constataram uma quase dissipação por completa dos sintomas iniciais de injúrias proporcionados pelos herbicidas tebuthiuron, ametryn e a mistura ametryn + trifloxysulfuronsodium.

Aos 35 DAA, verificou-se completa dissipação dos sintomas iniciais de injúrias promovidos pelos tratamentos químicos em todas as variedades de cana-de-açúcar. Dissipação esta, atribuída a rápida emissão de folhas novas sem sintomas de injúrias. Provavelmente favorecidas pelas condições climáticas durante o período avaliado, (Figura 1). De acordo com Veline et. al (1993), a rápida recuperação de plantas de cana-de-açúcar tratadas com herbicidas, pode ser atribuída a precipitação pluviométrica durante a condução do estudo, o que favorece o desenvolvimento da cultura. Ainda, considera-se que as variedades de cana-de-açúcar podem apresentar padrões diferenciados de crescimento e superação da intoxicação e que este padrão de recuperação pouco depende da intensidade inicial de intoxicação.

Tabela 4. Porcentagem de fitotoxicidade em diferentes variedades de cana-de-açúcar aos 7, 14, 28 e 35 dias após a aplicação de diversos herbicidas. Botucatu/SP, 2007.

\begin{tabular}{|c|c|c|c|c|c|c|}
\hline \multirow{2}{*}{ Variedades } & \multirow{2}{*}{ Tratamentos } & \multirow{2}{*}{$\begin{array}{c}\text { Dose } \\
\left(\mathrm{g} \mathrm{ha}^{-1}\right)\end{array}$} & \multicolumn{4}{|c|}{ Dias após a aplicação } \\
\hline & & & 7 & 14 & 28 & 35 \\
\hline \multirow{4}{*}{ 1. SP 832847} & topramezone $^{1}$ & 70 & 22,5 & 7,5 & 1,3 & 0,0 \\
\hline & topramezone ${ }^{1}+$ tebuthiuron & $70+1000$ & 14,3 & 3,3 & 0,5 & 0,0 \\
\hline & topramezone $^{1}+$ tebuthiuron & $100+1000$ & 18,8 & 8,8 & 3,3 & 0,0 \\
\hline & ametryn + tebuthiuron & $1500+1000$ & 10,8 & 2,0 & 0,5 & 0,0 \\
\hline
\end{tabular}


Tabela. 4 continuaçãa...

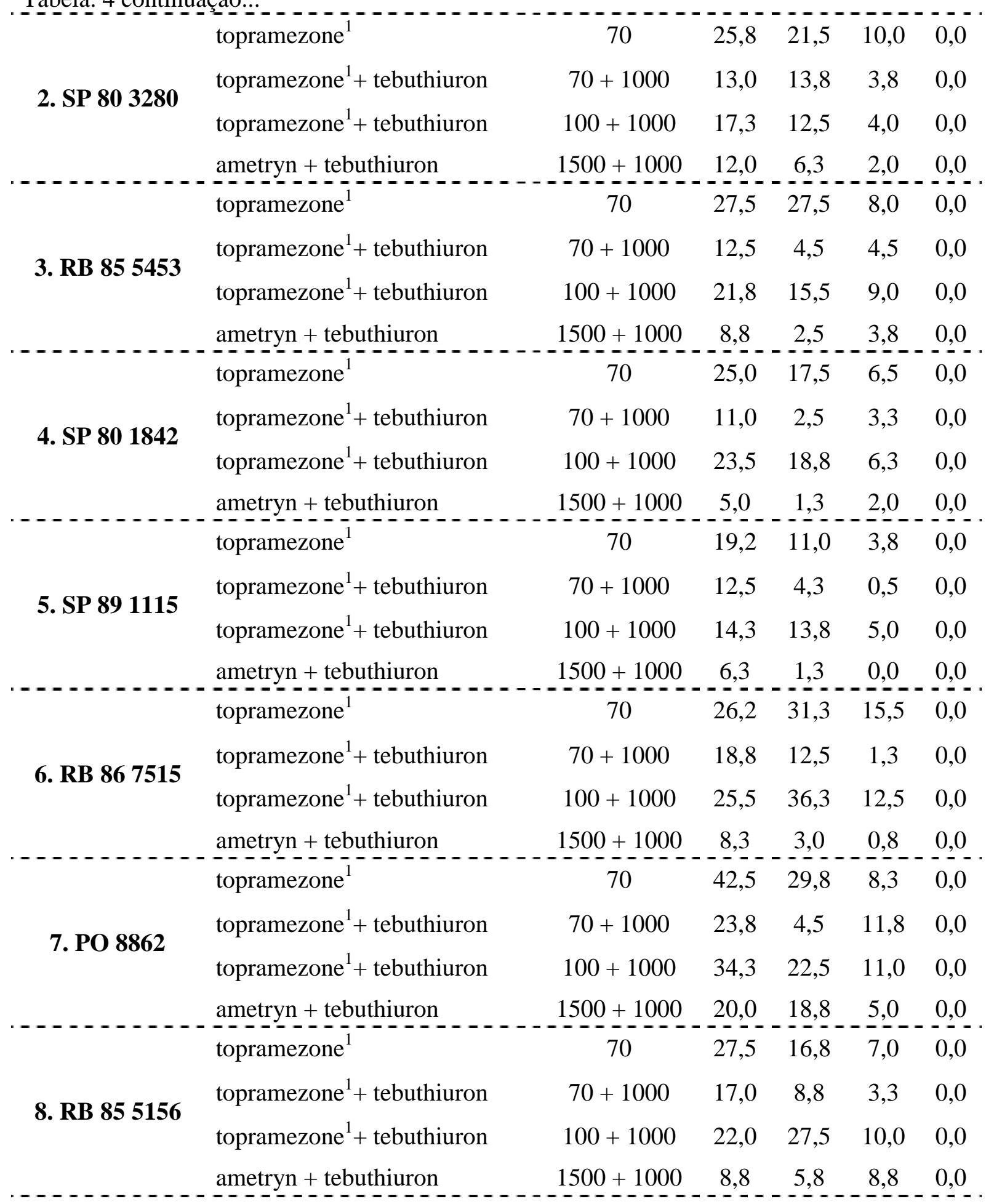




\begin{tabular}{|c|c|c|c|c|c|c|}
\hline & topramezone $^{1}$ & 70 & 22,0 & 12,5 & 8,3 & 0,0 \\
\hline \multirow{3}{*}{ 9. SP 801816} & topramezone $^{1}+$ tebuthiuron & $70+1000$ & 13,0 & 11,3 & 8,5 & 0,0 \\
\hline & topramezone $^{1}+$ tebuthiuron & $100+1000$ & 18,8 & 17,5 & 10,0 & 0,0 \\
\hline & ametryn + tebuthiuron & $1500+1000$ & 13,3 & 5,0 & 6,3 & 0,0 \\
\hline & topramezone $^{1}$ & 70 & 33,8 & 23,0 & 13,0 & 0,0 \\
\hline \multirow{3}{*}{ 10. SP81 3250} & topramezone $^{1}+$ tebuthiuron & $70+1000$ & 19,3 & 10,0 & 2,0 & 0,0 \\
\hline & topramezone $^{1}+$ tebuthiuron & $100+1000$ & 32,0 & 21,3 & 7,5 & 0,0 \\
\hline & ametryn + tebuthiuron & $1500+1000$ & 7,5 & 3,0 & 3,8 & 0,0 \\
\hline
\end{tabular}

- adicionou-se $\left(0,25 \%\right.$ de $\left.\mathrm{v} / \mathrm{v}^{-1}\right)$ do adjuvante Dash nos tratamentos contendo topramezone

Na Tabela 5 estão apresentados os resultados das avaliações de altura média de plantas $(\mathrm{cm})$ de cana-de-açúcar tratadas com diferentes herbicidas. Verifica-se que os fatores principais, Variedade e Herbicida, atuaram de forma isolado sobre este parâmetro, conforme pode ser observado pela não significância da interação (Variedade x Herbicida). Assim, os fatores apresentaram um comportamento independente entre si, ou seja, os efeitos observados nas variedades devem ser atribuídas as diferenças genotípicas das mesmas e não a ação dos tratamentos químicos. Observa-se ainda, efeito isolado do fator Herbicida sobre este parâmetro.

Tabela 5. Altura de plantas (cm) de cana planta, após a aplicação de diversos herbicidas em diferentes períodos de avaliação. Botucatu/SP, 2007.

\begin{tabular}{llccc}
\hline Variedades & Tratamentos & Dose $\left(\mathbf{g ~ h a}^{-\mathbf{1}}\right)$ & 28 DAA & 64 DAA \\
\hline & topramezone $^{1}$ & 70 & 131,6 & 184,3 \\
& topramezone $^{1}+$ tebuthiuron & $70+1000$ & 129,1 & 177,1 \\
\multirow{2}{*}{ 1. SP 83 2847 } & topramezone ${ }^{1}+$ tebuthiuron & $100+1000$ & 119,2 & 172,7 \\
& ametryn + tebuthiuron & $1500+1000$ & 128,4 & 172,2 \\
& testemunha & - & 134,5 & 190,5 \\
\end{tabular}


Tabela. 5 continuação..

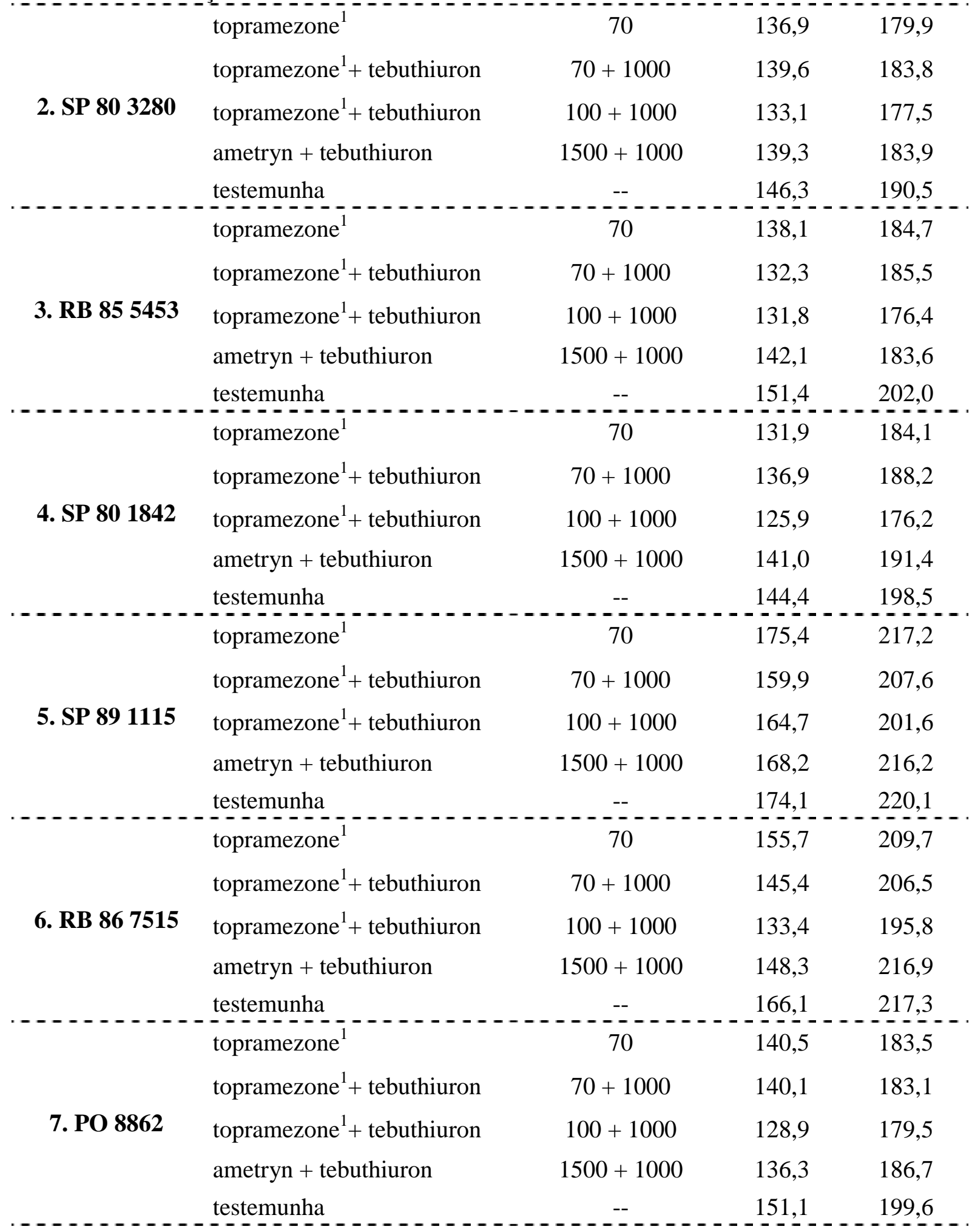


Tabela. 5 continuação..

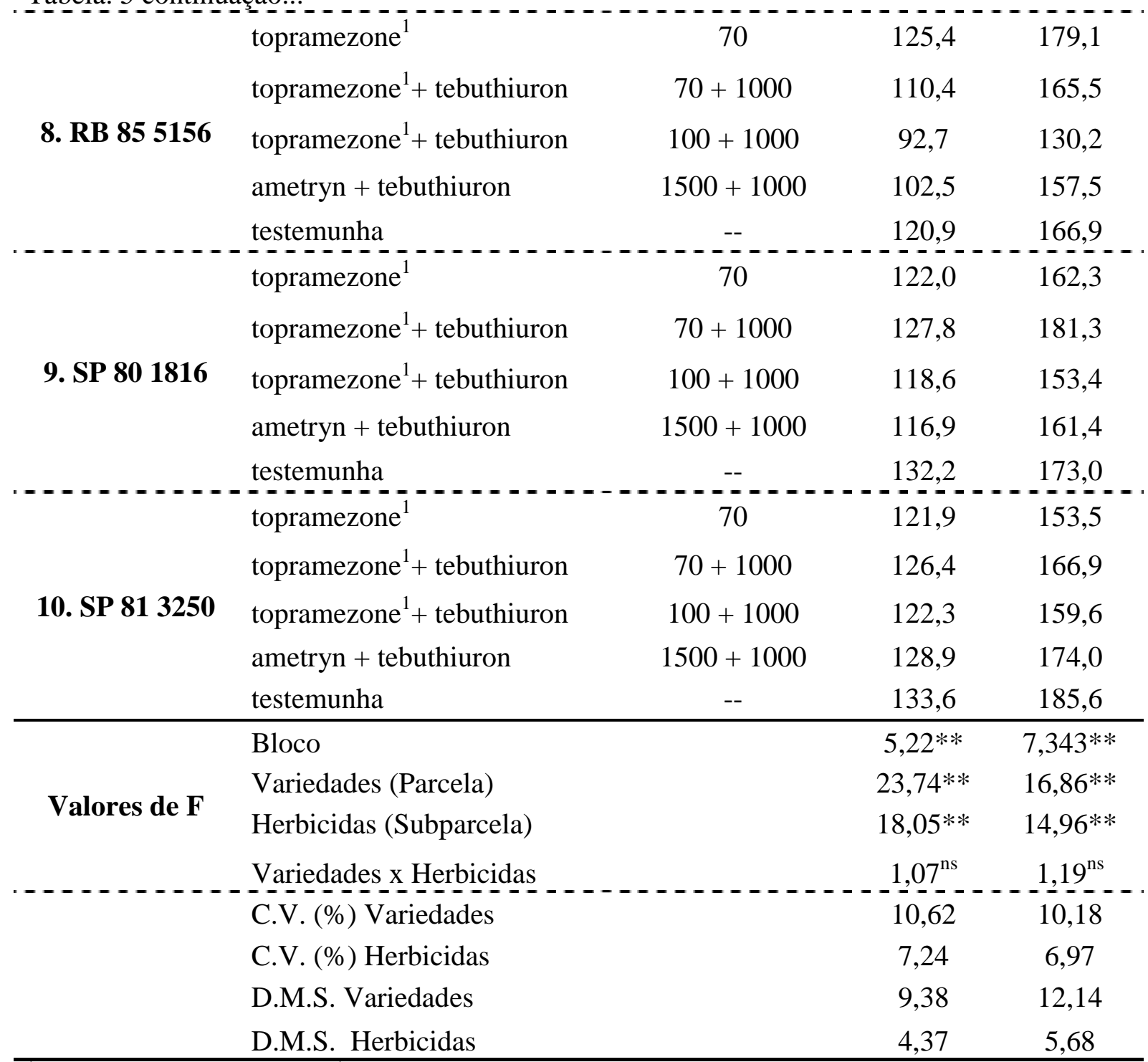

${ }^{1}$ - adicionou-se $\left(0,25 \% \mathrm{de} \mathrm{v} / \mathrm{v}^{-1}\right)$ do adjuvante Dash nos tratamentos contendo topramezone

**-Significativo ao nível de $1 \%$ de probabilidade;

ns - Não significativo;

Na Tabela 6 estão apresentados as médias de altura de plantas das diversas variedades de cana-de-açúcar (efeito de Variedades). Observa-se que ocorreram diferenças significativas entre as variedades estudadas. Nota-se que a variedade SP 891115 foi a que apresentou maior altura média de plantas aos 28 e 64 DAA, apesar de aos 64 DAA não ter diferenciado estatisticamente da Variedade RB 86 7515, com as médias de altura de 212,5 e $209,2 \mathrm{~cm}$, respectivamente. 
Tabela 6. Efeito de diversas variedades de cana-de-açúcar sobre altura de plantas (cm) submetidas as diferentes herbicidas. Botucatu/SP, 2007.

\begin{tabular}{lcc}
\hline \multirow{2}{*}{ Variedades } & \multicolumn{2}{c}{ Altura média de plantas } \\
\cline { 2 - 3 } 1. SP 83 2847 & 28 DAA & 64 DAA \\
2. SP 80 3280 & $128,5 \mathrm{de}$ & $179,3 \mathrm{bc}$ \\
3. RB 85 5453 & $139,0 \mathrm{c}$ & $183,1 \mathrm{~b}$ \\
4. SP 80 1842 & $139,1 \mathrm{c}$ & $186,4 \mathrm{~b}$ \\
5. SP 89 1115 & $136,0 \mathrm{~cd}$ & $187,7 \mathrm{~b}$ \\
6. RB 86 7515 & $168,5 \mathrm{a}$ & $212,5 \mathrm{a}$ \\
7. PO 8862 & $149,8 \mathrm{~b}$ & $209,2 \mathrm{a}$ \\
8. RB 85 5156 & $139,3 \mathrm{c}$ & $186,5 \mathrm{~b}$ \\
9. SP 80 1816 & $110,4 \mathrm{f}$ & $159,8 \mathrm{~d}$ \\
$\mathbf{1 0 . S P ~ 8 1 ~ 3 2 5 0}$ & $123,5 \mathrm{e}$ & $166,3 \mathrm{~d}$ \\
\hline Valores de F & $126,6 \mathrm{e}$ & $167,9 \mathrm{~cd}$ \\
C.V. $(\%)$ & $23,7 * *$ & $16,9 * *$ \\
D.M.S. & 10,6 & 10,2 \\
\hline
\end{tabular}

**-Significativo ao nível de $1 \%$ de probabilidade;

Médias seguidas de mesma letra na coluna, não diferem estatisticamente entre si, pelo teste Tukey $(P>0,05)$.

Na Tabela 7 estão apresentados às medias de altura de plantas de canade-açúcar em função dos herbicidas testados (efeito de Herbicidas). Observa-se que independente dos períodos avaliados, a testemunha apresentou maior crescimento em relação aos tratamentos com herbicidas, ou seja, todos os tratamentos químicos influenciaram negativamente de alguma forma o crescimento de plantas de cana-de-açúcar até aos 64 DAA. Ainda, notou-se que o tratamento que proporcionou maiores injúrias iniciais às plantas (a maior dose da mistura topramezone + tebuthiuron) também determinou uma redução maior na altura de plantas. 
Tabela 7. Efeito de diversos herbicidas sobre altura de plantas $(\mathrm{cm})$ de dez variedades de canade-açúcar em diferentes períodos de avaliação. Botucatu/SP, 2007.

\begin{tabular}{|c|c|c|c|}
\hline \multirow{2}{*}{ Tratamentos } & \multirow{2}{*}{ Dose $\left(\mathrm{g} \mathrm{ha}^{-1}\right)$} & \multicolumn{2}{|c|}{ Altura média de plantas } \\
\hline & & 28 DAA & 64 DAA \\
\hline topramezone $^{1}$ & 70 & $138,0 \mathrm{~b}$ & $183,8 \mathrm{~b}$ \\
\hline topramezone ${ }^{1}+$ tebuthiuron & $70+1000$ & $134,8 \mathrm{~b}$ & $184,5 \mathrm{~b}$ \\
\hline topramezone ${ }^{1}+$ tebuthiuron & $100+1000$ & $127,1 \mathrm{c}$ & $172,3 \mathrm{c}$ \\
\hline ametryn + tebuthiuron & $1500+1000$ & $135,2 \mathrm{~b}$ & $184,4 b$ \\
\hline testemunha & -- & $145,5 \mathrm{a}$ & $194,4 \mathrm{a}$ \\
\hline Valores de F & & $18,1 * *$ & $14,9 * *$ \\
\hline C.V. $(\%)$ & & 7,2 & 6,9 \\
\hline D.M.S. & & 4,4 & 5,6 \\
\hline
\end{tabular}

Azania et al. (2006) avaliando a seletividade de vários herbicidas aplicados em pós-emergência inicial e tardia sobre as plantas de cana-de-açúcar, variedade RB 835089 , observaram que os herbicidas que teriam proporcionados elevados sintomas visuais de intoxicação das plantas foram também os que proporcionaram as menores alturas. Observação semelhante, em um estudo feito por Constantin et al. (2000), no qual estudou a seletividade e a eficiência do controle do herbicida diclosulan sobre a variedade SP 792233 , também constataram que o tratamento mais fitotóxico às plantas de cana-de-açúcar apresentaram a maior redução em altura aos 60 DAA.

Na Tabela 8 estão apresentados os resultados do perfilhamento das variedades de cana-de-açúcar. Não foi notado, estatisticamente, nenhum efeito da interação (Variedades x Herbicidas). Terra (2003) em um estudo de seletividade com os herbicidas diclosulam, ametryn e ametryn + tryfloxisulfuron-sodium a onze variedades de cana-deaçúcar, constatou observações semelhantes, no qual, não foi verificado a interação significativa entre (Herbicidas x Variedades), sendo somente os efeitos de forma isolados, como ora constatados também.

Na Tabela 9 estão apresentados os números de perfilhos de 10 variedades de cana-de-açúcar (efeito de Variedades). Verificou-se a existência de diferenças 
varietais quanto aos números de perfilhos. Registrou-se um aumento substancial dos números de perfilhos por metro, dos 28 DAA para 64 DAA independente da variedade de cana-deaçúcar analisada, com maior destaque para a variedade SP 81 3250, com uma média de 21,2 perfilhos $\mathrm{m}^{-1}$, sendo que mais próximo da colheita observou-se uma queda considerável do número de perfilhos para todas as variedades.

Para Silva (2003), a possível explicação para esse comportamento de perfilhamento intenso no início do ciclo e a queda a partir do terceiro mês após a semeadura, deve-se a alta luminosidade disponível e espaço aéreo para exploração das plantas, conforme os primeiros perfilhos vão se desenvolvendo e ocupando maior espaço no solo e no ar, as suas folhas vão sombreando aqueles que brotam tardiamente e, que são menores, sendo estes primeiros mais eficientes na competição por água e luz, fazendo com que esses perfilhos mais novos não consigam sobreviver, morrendo antes de se tornarem plantas completas.

Tabela 8. Efeito de diversos herbicidas sobre números de perfilhos $\left(\mathrm{m}^{-1}\right)$ de dez variedades de cana-de-açúcar em diferentes períodos de avaliação. Botucatu/SP, 2007/08.

\begin{tabular}{|c|c|c|c|c|c|}
\hline \multirow{2}{*}{ Variedade } & \multirow{2}{*}{ Tratamentos } & \multirow{2}{*}{$\begin{array}{c}\text { Dose } \\
\left(\mathrm{g} \mathrm{ha}^{-1}\right)\end{array}$} & \multicolumn{3}{|c|}{ Numero de perfilhos (m) } \\
\hline & & & 28 DAA & 64 DAA & 300 DAA \\
\hline \multirow{5}{*}{ 1. SP 832847} & topramezone $^{1}$ & 70 & 13,1 & 18,1 & 12,0 \\
\hline & topramezone ${ }^{1}+$ tebuthiuron & $70+1000$ & 13,1 & 15,7 & 13,1 \\
\hline & topramezone ${ }^{1}+$ tebuthiuron & $100+1000$ & 12,4 & 15,8 & 14,6 \\
\hline & ametryn + tebuthiuron & $1500+1000$ & 15,0 & 17,3 & 14,7 \\
\hline & testemunha & -- & 14,7 & 16,9 & 11,6 \\
\hline \multirow{5}{*}{ 2. SP 803280} & topramezone & 70 & 16,3 & 17,1 & 10,9 \\
\hline & topramezone ${ }^{1}+$ tebuthiuron & $70+1000$ & 16,1 & 18,8 & 11,6 \\
\hline & topramezone ${ }^{1}+$ tebuthiuron & $100+1000$ & 16,6 & 20,3 & 12,2 \\
\hline & ametryn + tebuthiuron & $1500+1000$ & 16,6 & 18,9 & 12,0 \\
\hline & testemunha & -- & 18,3 & 18,4 & 11,1 \\
\hline
\end{tabular}


Tabela 8. Continuação...

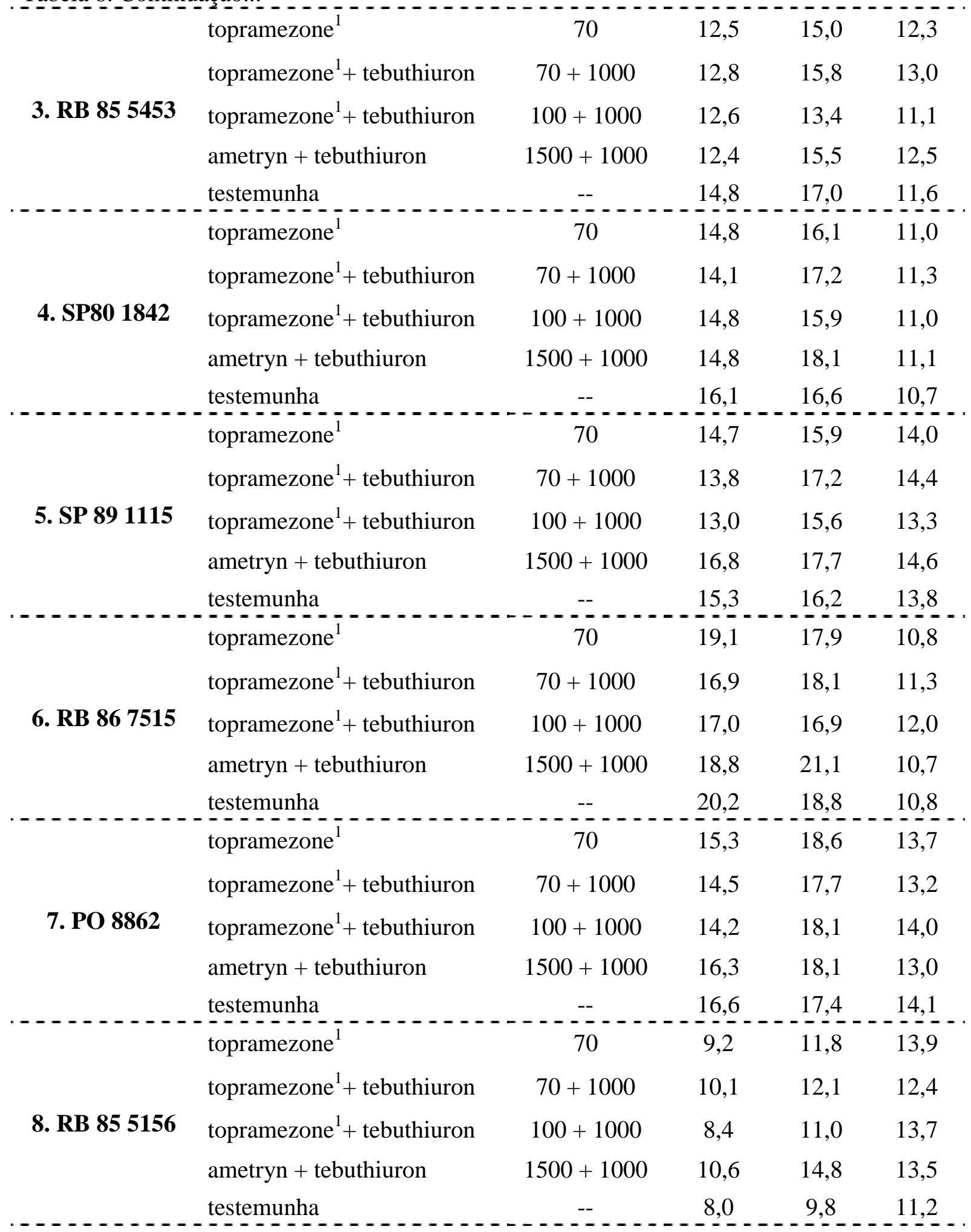


Tabela 8. Continuação...

\begin{tabular}{|c|c|c|c|c|c|}
\hline & topramezone $^{1}$ & 70 & 12,3 & 13,7 & 11,5 \\
\hline \multirow{4}{*}{ 9. SP 801816} & topramezone $^{1}+$ tebuthiuron & $70+1000$ & 12,7 & 16,0 & 12,6 \\
\hline & topramezone $^{1}+$ tebuthiuron & $100+1000$ & 10,9 & 13,8 & 12,8 \\
\hline & ametryn + tebuthiuron & $1500+1000$ & 12,2 & 15,3 & 12,7 \\
\hline & testemunha & -- & 12,8 & 16,6 & 12,3 \\
\hline \multirow{5}{*}{ 10. SP 813250} & topramezone ${ }^{1}$ & 70 & 17,1 & 19,6 & 14,5 \\
\hline & topramezone $^{1}+$ tebuthiuron & $70+1000$ & 16,2 & 21,7 & 14,1 \\
\hline & topramezone $^{1}+$ tebuthiuron & $100+1000$ & 15,5 & 19,8 & 14,2 \\
\hline & ametryn + tebuthiuron & $1500+1000$ & 18,8 & 22,3 & 14,7 \\
\hline & testemunha & -- & 21,9 & 22,4 & 14,1 \\
\hline \multirow{8}{*}{ Valores de $\mathbf{F}$} & Bloco & & $2,00^{\mathrm{ns}}$ & $2,24^{\mathrm{ns}}$ & $5,73^{*}$ \\
\hline & Variedades (parcelas) & & $12,28 * *$ & $9,35 * *$ & $3,50 *$ \\
\hline & Herbicidas (subparcelas) & & $7,75 * *$ & $4,80 * *$ & $3,17 *$ \\
\hline & Variedades x Herbicidas & & $0,81^{\mathrm{ns}}$ & $1,06^{\mathrm{ns}}$ & $1,36^{\mathrm{ns}}$ \\
\hline & C.V. (\%) Variedades & & 24,2 & 21,7 & 22,4 \\
\hline & C.V. (\%) Herbicidas & & 14,6 & 12,3 & 9,4 \\
\hline & D.M.S. Variedades & & 3,8 & 4,0 & 3,1 \\
\hline & D.M.S. Herbicidas & & 1,3 & 1,3 & 0,7 \\
\hline
\end{tabular}

T - adicionou-se $\left(0,25 \%\right.$ de $\left.\mathrm{v} / \mathrm{v}^{-1}\right)$ do adjuvante Dash nos tratamentos contendo topramezone

**-Significativo ao nível de $1 \%$ de probabilidade;

*- Significativo ao nível de $5 \%$ de probabilidade;

ns - Não significativo; 
Tabela 9. Efeito de diversas variedades de cana-de-açúcar sobre os números de perfilhos submetidas as diferentes herbicidas. Botucatu/SP, 2007/08.

\begin{tabular}{|c|c|c|c|}
\hline \multirow{2}{*}{ Variedades } & \multicolumn{3}{|c|}{ Numero de perfilhos (m) } \\
\hline & 28 DAA & 64 DAA & 300 DAA \\
\hline 1. SP 832847 & $13,6 \mathrm{bc}$ & $16,8 \mathrm{~b}$ & $13,2 \mathrm{ab}$ \\
\hline 2. SP 803280 & $16,8 \mathrm{ab}$ & $18,7 \mathrm{ab}$ & $11,5 \mathrm{ab}$ \\
\hline 3. RB 855453 & $13,0 \mathrm{bcd}$ & $15,3 \mathrm{bc}$ & $12,1 \mathrm{ab}$ \\
\hline 4. SP 801842 & $14,9 \mathrm{abc}$ & $16,8 \mathrm{~b}$ & $11,0 \mathrm{~b}$ \\
\hline 5. SP 891115 & $14,7 \mathrm{abc}$ & $16,5 \mathrm{~b}$ & $14,0 \mathrm{ab}$ \\
\hline 6. RB 867515 & $18,4 \mathrm{a}$ & $18,6 \mathrm{ab}$ & $11,2 \mathrm{ab}$ \\
\hline 7. PO 8862 & $15,3 \mathrm{abc}$ & $18,0 \mathrm{ab}$ & $13,6 \mathrm{ab}$ \\
\hline 8. RB 855156 & $9,2 \mathrm{~d}$ & $11,9 \mathrm{c}$ & $12,9 \mathrm{ab}$ \\
\hline 9. SP 801816 & $12,2 \mathrm{~cd}$ & $15,1 \mathrm{bc}$ & $12,4 \mathrm{ab}$ \\
\hline 10. SP 813250 & $17,9 \mathrm{a}$ & $21,2 \mathrm{a}$ & $14,3 \mathrm{a}$ \\
\hline Valores de F & $12,28 * *$ & $9,35 * *$ & $3,50 *$ \\
\hline C.V. $(\%)$ & 24,2 & 21,7 & 22,4 \\
\hline D.M.S. & 3,8 & 4,0 & 3,1 \\
\hline
\end{tabular}

Na Tabela 10 estão apresentadas as avaliações dos perfilhos de plantas de cana-de-açúcar em função de herbicidas testados (efeito de Herbicidas). Aos 28 DAA observa-se que ocorreu efeito dos herbicidas no perfilhamento da cultura, principalmente a maior dose do topramezone + tebuthiuron e o tratamento isolado de topramezone. Ou seja, o efeito fitotóxico inicial causado por este tratamento teve ação supressiva sobre o perfilhamento da cana até aos 64 DAA. Já, ao final das avaliações, não foi constatado nenhum efeito prejudicial dos tratamentos químicos sobre o perfilhamento da cultura, visto que a testemunha apresentou valor igual ou inferior às parcelas tratadas com herbicidas, o que foi semelhante as observações descritas por Velini et al. (2000) e Terra (2003) ao estudarem a seletividade dos diferentes herbicidas aplicados em pré-emergência ou em pós-emergência inicial sobre as diversas variedades de cana-de-açúcar (cana-planta). Estes pesquisadores concluíram que não havia efeitos prejudiciais dos herbicidas sobre os números de colmos. 
Maciel et al. (2008), avaliando a eficiência e a seletividade dos herbicidas trifloxysulfuron-sodium + ametryn e hexazinone + diuron em função da tecnologia de aplicação e do manejo mecânico da palha de cana-de-açúcar na linha de plantio, também observaram que, independentemente de manejo adotado, não havia efeito supressivo dos herbicidas quanto ao número de perfilhos e diâmetros dos colmos aos 90 DAA.

Tabela 10. Efeito dos diversos herbicidas sobre os números de perfilhos de dez variedades de cana-de-açúcar em diferentes períodos de avaliação. Botucatu/SP, 2007/08.

\begin{tabular}{|c|c|c|c|c|}
\hline \multirow{2}{*}{ Tratamentos } & \multirow{2}{*}{ Dose $\left(\mathrm{g} \mathrm{ha}^{-1}\right)$} & \multicolumn{3}{|c|}{ Número de perfilhos (m) } \\
\hline & & 28 DAA & 64 DAA & 300 DAA \\
\hline topramezone $^{1}$ & 70 & $14,4 \mathrm{bc}$ & $16,4 \mathrm{~b}$ & $12,5 \mathrm{ab}$ \\
\hline topramezone ${ }^{1}+$ tebuthiuron & $70+1000$ & $14,0 \mathrm{bc}$ & $17,0 \mathrm{ab}$ & $12,7 \mathrm{ab}$ \\
\hline topramezone ${ }^{1}+$ tebuthiuron & $100+1000$ & $13,5 \mathrm{c}$ & $16,1 \mathrm{~b}$ & $12,9 \mathrm{a}$ \\
\hline ametryn + tebuthiuron & $1500+1000$ & $15,2 \mathrm{ab}$ & $17,9 \mathrm{a}$ & $12,9 \mathrm{a}$ \\
\hline testemunha & -- & $15,9 \mathrm{a}$ & $17,0 \mathrm{ab}$ & $12,1 \mathrm{~b}$ \\
\hline Valores de F & & $7,75 * *$ & $4,80^{* *}$ & $3,17 *$ \\
\hline C.V. $(\%)$ & & 14,6 & 12,3 & 9,4 \\
\hline D.M.S. & & 1,3 & 1,3 & 0,7 \\
\hline
\end{tabular}

Na Tabela 11, estão apresentados os resultados dos parâmetros produtivos: comprimento, diâmetro e rendimento de colmos das variedades de cana-de-açúcar tratadas com diferentes herbicidas. Nota-se que não houve efeito significativo da interação (Variedade x Herbicida), sendo os efeitos destes fatores independentes. Houve apenas os efeito dos fatores principais de forma isolado, Variedade e Herbicida, sendo que para herbicidas ocorreu com o rendimento.

Os efeitos observados nas variedades devem ser atribuídos às diferenças genotípicas e não a ação dos herbicidas. Nota-se que as diferenças observadas em cada parâmetro analisado, não ocorreu em uma mesma variedade, com superioridade para mais de um dos componentes. Terra (2003), descreve estas diferenças observadas como, ao 
fato, talvez, das características genéticas da população de cada cultivar estarem atuando de forma diferente, conforme as condições ambientais presentes.

Tabela 11. Efeito de diferentes herbicidas sobre o comprimento, diâmetro e rendimento de colmos de dez variedades de cana-de-açúcar, por ocasião da colheita. Botucatu/SP, 2007/08.

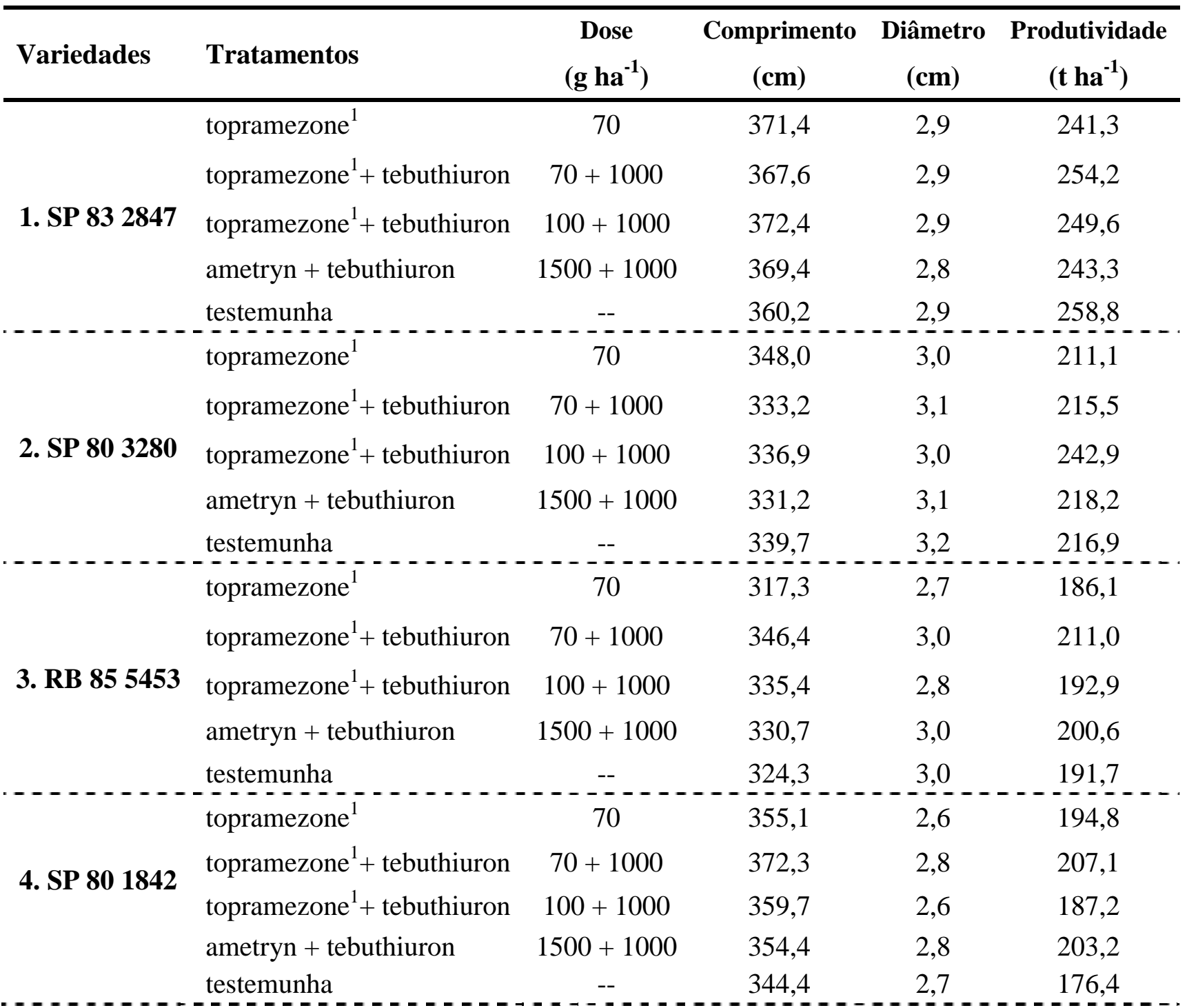


Tabela 11. continuaçãa....

\begin{tabular}{|c|c|c|c|c|c|}
\hline & topramezone $^{1}$ & 70 & 322,4 & 3,1 & 241,3 \\
\hline \multirow{4}{*}{ 5. SP 891115} & topramezone $^{1}+$ tebuthiuron & $70+1000$ & 327,8 & 3,1 & 237,6 \\
\hline & topramezone ${ }^{1}+$ tebuthiuron & $100+1000$ & 334,9 & 3,1 & 243,6 \\
\hline & ametryn + tebuthiuron & $1500+1000$ & 338,9 & 3,1 & 250,4 \\
\hline & testemunha & $\therefore$ & 322,7 & 3,0 & 235,9 \\
\hline & topramezone $^{1}$ & 70 & 388,7 & 3,2 & 241,3 \\
\hline \multirow{3}{*}{ 6. RB 867515} & topramezone $^{1}+$ tebuthiuron & $70+1000$ & 392,5 & 3,3 & 252,1 \\
\hline & topramezone $^{1}+$ tebuthiuron & $100+1000$ & 383,7 & 3,1 & 248,6 \\
\hline & ametryn + tebuthiuron & $1500+1000$ & 375,7 & 3,3 & 258,5 \\
\hline \multirow{6}{*}{ 7. PO 8862} & testemunha & - $-{ }_{-}^{-}-\ldots$ & 384,9 & 3,2 & 261,9 \\
\hline & topramezone $^{1}$ & 70 & 326,1 & 3,0 & 257,6 \\
\hline & topramezone $^{1}+$ tebuthiuron & $70+1000$ & 323,7 & 3,3 & 276,7 \\
\hline & topramezone $^{1}+$ tebuthiuron & $100+1000$ & 313,5 & 3,1 & 259,5 \\
\hline & ametryn + tebuthiuron & $1500+1000$ & 330,2 & 3,0 & 253,3 \\
\hline & testemunha & -- & 325,8 & 3,0 & 264 \\
\hline \multirow{4}{*}{ 8. RB 855156} & topramezone $^{1-}$ & 70 & 308,4 & 2,9 & 218,2 \\
\hline & topramezone $^{1}+$ tebuthiuron & $70+1000$ & 318,1 & 3,0 & 212,6 \\
\hline & topramezone $^{1}+$ tebuthiuron & $100+1000$ & 324,0 & 2,8 & 207,7 \\
\hline & ametryn + tebuthiuron & $1500+1000$ & 336,2 & 2,9 & 219,7 \\
\hline & testemunha & $-\overline{-}$. & 330,4 & 3,0 & 201,7 \\
\hline & topramezone $^{1}$ & 70 & 318,6 & 2,9 & 183,3 \\
\hline \multirow{3}{*}{ 9. SP 801816} & topramezone $^{1}+$ tebuthiuron & $70+1000$ & 336,1 & 2,7 & 209,9 \\
\hline & topramezone $^{1}+$ tebuthiuron & $100+1000$ & 328,3 & 2,9 & 202,5 \\
\hline & ametryn + tebuthiuron & $1500+1000$ & 341,3 & 2,8 & 225,3 \\
\hline \multirow{6}{*}{ 10. SP 813250} & testemunha & -- & 319,6 & 2,8 & 182,9 \\
\hline & topramezone $^{1}$ & 70 & 332,5 & 2,8 & 221,2 \\
\hline & topramezone $^{1}+$ tebuthiuron & $70+1000$ & 324,2 & 2,8 & 230,4 \\
\hline & topramezone $^{1}+$ tebuthiuron & $100+1000$ & 348,6 & 2,7 & 232,7 \\
\hline & ametryn + tebuthiuron & $1500+1000$ & 336,7 & 2,8 & 237,4 \\
\hline & testemunha & -- & 313,3 & 2,9 & 233,8 \\
\hline
\end{tabular}


Tabela 11. Continuação...

\begin{tabular}{clccc}
\hline \multirow{2}{*}{ Valores de $\mathbf{F}$} & Bloco & $1,05^{\mathrm{ns}}$ & $0,13^{\mathrm{ns}}$ & $12,13^{* *}$ \\
& Variedades (parcelas) & $11,22^{* *}$ & $7,07^{* *}$ & $14,9^{* *}$ \\
& Herbicidas (subparcelas) & $1,45^{\mathrm{ns}}$ & $3,09^{\mathrm{ns}}$ & $4,90^{* *}$ \\
& Variedades x Herbicidas & $0,84^{\mathrm{ns}}$ & $1,57^{\mathrm{ns}}$ & $1,70^{\mathrm{ns}}$ \\
\hline C.V. (\%) Variedades & 8,3 & 8,9 & 12,8 \\
C.V. (\%) Herbicidas & 5,6 & 4,3 & 6,4 \\
D.M.S. Variedades & 30,79 & 0,28 & 31,45 \\
D.M.S. Herbicidas & 11,81 & 0,08 & 8,93 \\
\hline
\end{tabular}

${ }^{1}$ - adicionou-se $\left(0,25 \% \mathrm{v} / \mathrm{v}^{-1}\right)$ do adjuvante Dash nos tratamentos contendo topramezone

**-Significativo ao nível de $1 \%$ de probabilidade;

*-Significativo ao nível de $5 \%$ de probabilidade;

ns - Não significativo;

Na Tabela 12 estão apresentados as médias do diâmetro, comprimento e rendimento dos colmos das diversas variedades de cana-de-açúcar estudados. Observa-se que para estes parâmetros ocorreram diferenças entre as variedades conforme observado no teste F.

A variedade RB 867515 foi a que apresentou maior diâmetro de colmos, apesar de estatisticamente não diferir das variedades SP 80 3280, PO 8862, SP 89 1115 e RB 85 5156. Para o comprimento dos colmos também a variedade RB 867515 foi superior as demais, exceto a variedade SP 83 2847. Já, para o rendimento de colmos, a variedade PO 8862 apesar de estatisticamente não diferenciar das variedades RB 867515 e SP 83 2847, foi a que proporcionou maior produção com uma média de 262,2 toneladas por hectare. Ressalta-se que, essas diferenças observadas entre as variedades já eram esperados, por tratarem-se de genótipos diferentes. 
Tabela 12. Efeito de diversas variedades de cana-de-açúcar sobre o comprimento, diâmetro e produtividade de colmos submetidas as diferentes herbicidas. Botucatu/SP, 2007/08.

\begin{tabular}{lccc}
\hline Variedades & Comprimento $(\mathbf{c m})$ & Diâmetro $(\mathbf{c m})$ & Produtividade $\left(\mathbf{t ~ h a}^{-\mathbf{1}}\right)$ \\
\hline 1. SP 83 2847 & $368,2 \mathrm{ab}$ & $2,9 \mathrm{bcd}$ & $249,4 \mathrm{ab}$ \\
2. SP 80 3280 & $337,8 \mathrm{bcd}$ & $3,1 \mathrm{ab}$ & $220,9 \mathrm{bcde}$ \\
3. RB 85 5453 & $330,8 \mathrm{~cd}$ & $2,9 \mathrm{bcd}$ & $196,5 \mathrm{e}$ \\
4. SP 80 1842 & $357,2 \mathrm{abc}$ & $2,7 \mathrm{~d}$ & $193,7 \mathrm{e}$ \\
5. SP 89 1115 & $329,0 \mathrm{~cd}$ & $3,1 \mathrm{abc}$ & $241,8 \mathrm{abc}$ \\
6. RB 86 7515 & $385,1 \mathrm{a}$ & $3,2 \mathrm{a}$ & $252,5 \mathrm{a}$ \\
7. PO 8862 & $323,8 \mathrm{~d}$ & $3,1 \mathrm{ab}$ & $262,2 \mathrm{a}$ \\
8. RB 85 5156 & $323,4 \mathrm{~d}$ & $2,9 \mathrm{bcd}$ & $212,0 \mathrm{cde}$ \\
9. SP 80 1816 & $328,8 \mathrm{~cd}$ & $2,8 \mathrm{bcd}$ & $200,8 \mathrm{de}$ \\
10. SP 81 3250 & $331,1 \mathrm{~cd}$ & $2,8 \mathrm{~cd}$ & $231,1 \mathrm{abcd}$ \\
\hline Valores de F & $11,23^{* *}$ & $7,07 * *$ & $14,91 * *$ \\
C.V. $(\%)$ & 8.2 & 8,92 & 12,79 \\
\hline D.M.S. & 30,79 & 0,28 & 31,45 \\
\hline
\end{tabular}

**-Significativo ao nível de $1 \%$ de probabilidade;

Médias seguidas de mesma letra na coluna, não diferem estatisticamente entre si, pelo teste Tukey (P> 0,05).

Na Tabela 13 estão apresentados os dados relativos aos parâmetros: diâmetro, comprimento e produtividade dos colmos de cana-de-açúcar em função dos herbicidas testados. Observa-se que para o teste F, o comprimento e o diâmetro dos colmos não foram significativos, ou seja, não indicou a variação entre os herbicidas. Entretanto, para o rendimento de colmos, apesar de apresentar significância, porem os valores encontrados para as parcelas tratadas com os herbicidas foram iguais ou superiores aos valores encontrados na testemunha, sendo assim seletivos as diferenças entre as variedades estudadas.

Azania et al. (2001) avaliou a seletividade de imazapic, imazapyr e tebuthiuron as soqueiras de cana-de-açúcar, cultivar RB 83 5089, aplicado em pós-emergência inicial da cultura. Constatou que todos os produtos utilizados causaram leves sintomas de intoxicação inicial nas plantas, e sem prejuízo da produtividade e qualidade da matéria-prima. Corroborando os estudos feitos por (VELINE et at., 2000 e TERRA, 2003), no qual não observaram os efeitos dos herbicidas oxyfluorfen, ametryn, diclosulam e ametryn + 
tryfloxisulfuron-sodium sobre as características produtivas e tecnológicas de diferentes variedades de cana-de-açúcar.

Os resultados obtidos nestes estudos opõe-se a outro estudo, conduzido por Montorio et al. (2000) com a cultivar RB 83 5089, no qual mostrou que as características produtivas da cultura da cana-de-açúcar, como o diâmetro do colmo, comprimento do colmo e a produtividade de colmos eram influenciados de forma negativa pela aplicação de diversos herbicidas recomendados para a cultura, como ametryn e tebuthiuron.

A ausência na literatura sobre a aplicação do herbicida topramezone em cana-de-açúcar, limita a discussão dos resultados, podendo ser utilizados como referencia apenas as pesquisas utilizadas na cultura do milho. Soltani et al. (2007), avaliando a resposta de oito híbridos de milho doce a herbicida topramezone, verificou-se que a maior dose (300 g $\mathrm{ha}^{-1}$ ) proporcionou sintomas iniciais de injurias de $5 \%$ que se dissipou nos primeiros 28 DAA, e que não comprometeram às alturas de plantas, tamanho do sabugo, e a produção comercial de grãos. Contudo, estas conclusões podem ser precipitadas, uma vez que, neste estudo não se avaliou o efeito deste herbicida sobre a cultura do milho com as referidas doses.

Tabela 13. Efeito de diversos herbicidas sobre o comprimento, diâmetro e rendimento de colmos em dez variedades de cana-de-açúcar, por ocasião da colheita. Botucatu/SP, 2007/08.

\begin{tabular}{|c|c|c|c|c|}
\hline Tratamentos & $\begin{array}{c}\text { Dose } \\
\left(\mathrm{g} \mathrm{ha}^{-1}\right) \\
\end{array}$ & $\begin{array}{c}\text { Comprimento } \\
(\mathrm{cm}) \\
\end{array}$ & $\begin{array}{c}\text { Diâmetro } \\
(\mathrm{cm}) \\
\end{array}$ & $\begin{array}{c}\text { Produtividade } \\
\left(\mathbf{t} \mathbf{h a}^{-1}\right) \\
\end{array}$ \\
\hline topramezone $^{1}$ & 70 & 338,9 & 2,9 & $219,6 \mathrm{~b}$ \\
\hline topramezone ${ }^{1}+$ tebuthiuron & $70+1000$ & 344,2 & 3,0 & $230,7 \mathrm{a}$ \\
\hline topramezone $e^{1}+$ tebuthiuron & $100+1000$ & 343,7 & 2,9 & $226,7 \mathrm{ab}$ \\
\hline ametryn + tebuthiuron & $1500+1000$ & 344,5 & 3,0 & $231,0 \mathrm{a}$ \\
\hline testemunha & -- & 336,5 & 2,9 & $222,4 \mathrm{ab}$ \\
\hline Valores de F & & $1,45^{\mathrm{ns}}$ & $3,03^{\mathrm{ns}}$ & $4,90 *$ \\
\hline C.V. $(\%)$ & & 5,6 & 4,3 & 6,4 \\
\hline D.M.S. & & 11,81 & 0,08 & 8,93 \\
\hline
\end{tabular}


$\mathrm{Na}$ Tabela 14 estão apresentados os resultados dos parâmetros tecnológicos: teores de pol, brix, fibra e a quantidade de açúcar obtida nas dez variedades de cana-de-açúcar tratadas com diferentes herbicidas. Verifica-se, também, que não houve interação significativa entre Variedade x Herbicida. Os fatores analisados apresentaram um comportamento independente entre si, sendo significativo apenas o efeito de variedades. Como citado anteriormente, apresentação dos resultados isolados de cada fator, pode auxiliar a visualização de alguns fatores de interferência, como ambientais e características biológicas individuais das cultivares.

Tabela 14. Efeito de diversos herbicidas sobre os teores de pol, brix, fibra e produção de açúcar de dez variedades de cana-de-açúcar. Botucatu/SP, 2007/08.

\begin{tabular}{|c|c|c|c|c|c|c|}
\hline \multirow{2}{*}{ Variedade } & \multirow{2}{*}{ Tratamentos } & \multirow{2}{*}{$\begin{array}{c}\text { Dose } \\
\left(\mathrm{g} \mathrm{ha}^{-1}\right)\end{array}$} & \multicolumn{3}{|c|}{ Teor } & \multirow{2}{*}{$\begin{array}{l}\text { açúcar } \\
\left(t h^{-1}\right)\end{array}$} \\
\hline & & & Pol & Brix & Fibra & \\
\hline \multirow{5}{*}{ 1. SP83-2847 } & topramezone $^{1}$ & 70 & 13,8 & 19,0 & 12,6 & 33,5 \\
\hline & topramezone $^{1}+$ tebuthiuron & $70+1000$ & 14,5 & 19,3 & 12,7 & 36,7 \\
\hline & topramezone $^{1}+$ tebuthiuron & $100+1000$ & 14,4 & 19,3 & 12,8 & 35,1 \\
\hline & ametryn + tebuthiuron & $1500+1000$ & 14,6 & 20,0 & 13,6 & 35,2 \\
\hline & testemunha & -- & 14,9 & 20,0 & 13,2 & 38,1 \\
\hline \multirow{6}{*}{ 2. SP80-3280 } & topramezone $^{1}$ & 70 & 15,6 & 20,7 & 12,7 & 31,4 \\
\hline & topramezone $^{1}+$ tebuthiuron & $70+1000$ & 15,5 & 20,7 & 12,7 & 32,2 \\
\hline & topramezone $^{1}+$ tebuthiuron & $100+1000$ & 15,8 & 21,0 & 12,5 & 38,2 \\
\hline & ametryn + tebuthiuron & $1500+1000$ & 15,7 & 21,0 & 12,5 & 32,2 \\
\hline & testemunha & -- & 16,0 & 21,3 & 12,7 & 33,7 \\
\hline & topramezone ${ }^{1}$ & 70 & 15,1 & 20,0 & 12,8 & 28,9 \\
\hline \multirow{4}{*}{ 3. RB855453 } & topramezone ${ }^{1}+$ tebuthiuron & $70+1000$ & 15,5 & 20,3 & 12,9 & 31,2 \\
\hline & topramezone ${ }^{1}+$ tebuthiuron & $100+1000$ & 15,7 & 21,0 & 12,7 & 29,3 \\
\hline & ametryn + tebuthiuron & $1500+1000$ & 15,3 & 20,3 & 12,6 & 30,2 \\
\hline & testemunha & -- & 15,4 & 20,3 & 13,2 & 28,8 \\
\hline
\end{tabular}


Tabela 14. Continuação...

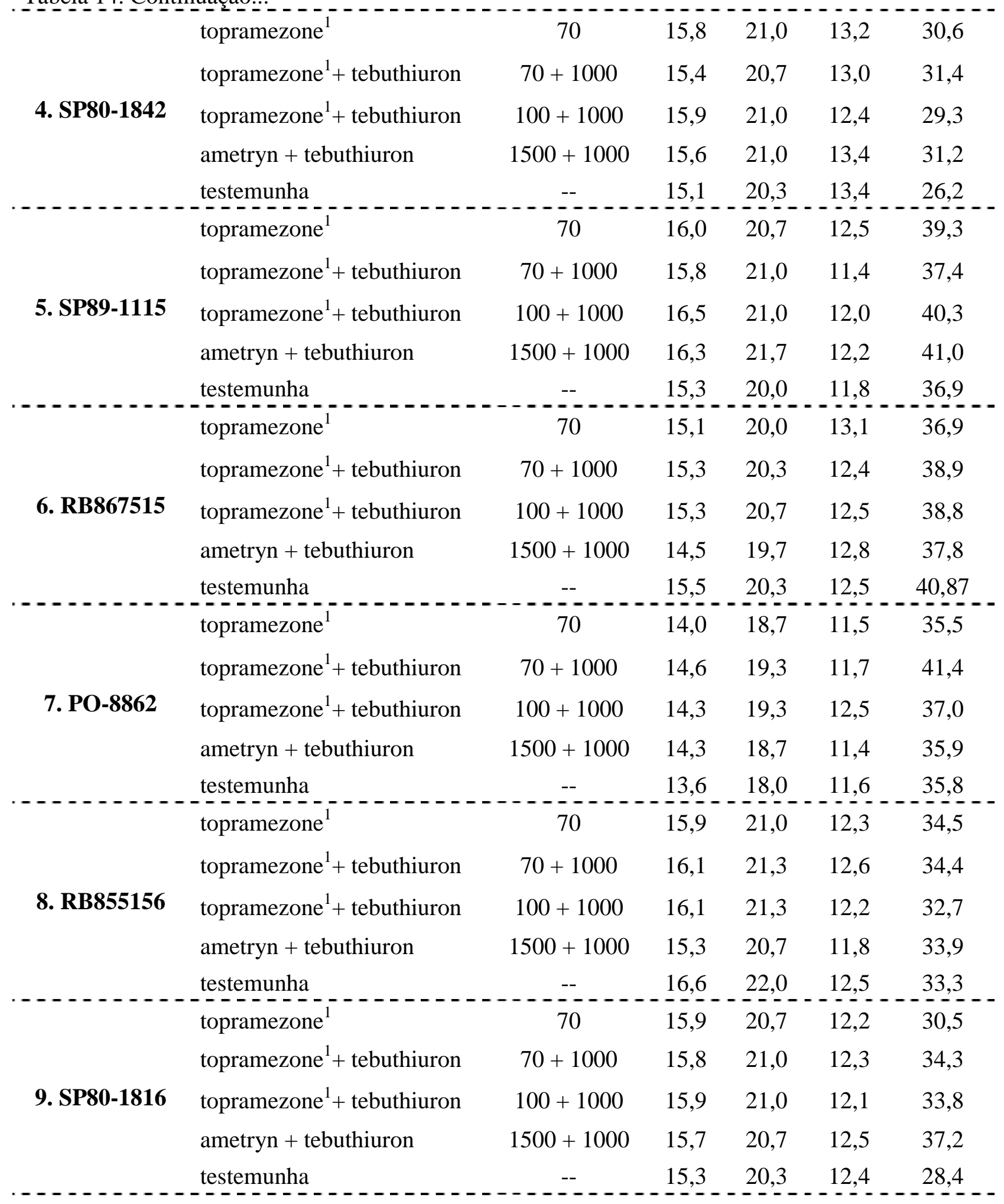


Tabela 14. Continuação....

\begin{tabular}{|c|c|c|c|c|c|c|}
\hline \multirow{5}{*}{ 10. SP81-3250 } & topramezone $^{1}$ & 70 & 15,3 & 20,0 & 12,6 & 34,3 \\
\hline & topramezone $^{1}+$ tebuthiuron & $70+1000$ & 15,6 & 20,7 & 13,0 & 36,9 \\
\hline & topramezone ${ }^{1}+$ tebuthiuron & $100+1000$ & 15,8 & 21,0 & 13,0 & 36,8 \\
\hline & ametryn + tebuthiuron & $1500+1000$ & 15,6 & 21,0 & 12,5 & 37,8 \\
\hline & testemunha & -- & 15,1 & 20,0 & 12,3 & 36,8 \\
\hline \multirow{8}{*}{ Valores de $\mathbf{F}$} & Bloco & & $4,6^{*}$ & $5,7^{*}$ & $1,5^{\mathrm{ns}}$ & $8,5^{*}$ \\
\hline & Variedades (parcelas) & & $5,8^{* *}$ & $4,4^{* *}$ & $1,0^{\mathrm{ns}}$ & $6,7 * *$ \\
\hline & Herbicidas (subparcelas) & & $0,1^{\mathrm{ns}}$ & $1,5^{\mathrm{ns}}$ & $0,9^{\mathrm{ns}}$ & $1,5^{\mathrm{ns}}$ \\
\hline & Variedades x Herbicidas & & $0,8_{-}^{\text {ns }}$ & $0,7^{\text {ns }}$ & $1,0_{-}^{\text {ns }}$ & $1,1_{-}^{\mathrm{ns}}$ \\
\hline & C.V. (\%) Variedades & & 6,8 & 6,7 & 33,6 & 14,2 \\
\hline & C.V. (\%) Herbicidas & & 7,4 & 4,1 & 31,1 & 10,9 \\
\hline & D.M.S. Variedades & & 1,4 & 1,8 & 5,6 & 6,4 \\
\hline & D.M.S. Herbicidas & & 0,8 & 0,6 & 2,9 & 2,7 \\
\hline
\end{tabular}

- adicionou-se $\left(0,25 \%\right.$ de $\left.\mathrm{v}^{-1} \mathrm{v}^{-1}\right)$ do adjuvante Dash nos tratamentos contendo topramezone

**-Significativo ao nível de $1 \%$ de probabilidade;

*- Significativo ao nível de 5\% de probabilidade;

ns - Não significativo;

Na Tabela 15, constam os teores de pol, brix e fibra e, a quantidade de açúcar produzido pelas variedades de cana-de-açúcar utilizadas neste estudo. Exceto o teor de fibra todos os parâmetros foram significativos pelo teste $\mathrm{F}$, indicando as diferenças entre as variedades nos principais quesitos tecnológicos de cana-de-açúcar.

Para o teor de brix, a variedade RB 855156 foi a que apresentou maior teor, apesar de só diferenciar da variedade PO 8862 que apresentou menor teor. Entretanto, as variações existentes entre as variedades, como já era esperadas, por tratarem de genótipos diferentes, apresentaram os teores de brix dentro de padrões aceitáveis pela indústria sucroalcoleira do Estado de São Paulo, no qual, considera que uma cana-de-açúcar para ser industrializada deve ter, entre outras características, um caldo que contenha no mínimo 18 brix, ou seja, 18\% de sólidos solúveis (FERNANDES, 2000).

Já, para o teor de pol, as variedades SP 891115 e RB 855156 foram as que proporcionaram maiores teores, nos quais, só diferenciaram estatisticamente das variedades PO 8862 e SP 832847 que produziram os menores teores. Também todas as variedades continham uma porcentagem de pol aceitável pelas indústrias sucroalcoleira do 
Estado de São Paulo (FERNANDES, 2000), no qual, uma cana para ser considerada madura deve apresentar pol\% cana igual ou maior a 14.4.

Tabela 15. Efeito de diversas variedades de cana-de-açúcar sobre os teores de pol, brix, fibra e produção de açúcar submetidas as diferentes herbicidas. Botucatu/SP, 2007/08.

\begin{tabular}{|c|c|c|c|c|}
\hline \multirow{2}{*}{ Variedades } & \multicolumn{3}{|c|}{ Teor } & \multirow{2}{*}{$\begin{array}{l}\text { Rendimento } \\
\left.\text { açúcar (t ha }{ }^{-1}\right)\end{array}$} \\
\hline & Pol & Brix & Fibra & \\
\hline 1. SP 832847 & $14,5 \mathrm{bc}$ & $19,5 \mathrm{bc}$ & $13,0 \mathrm{a}$ & $35,9 \mathrm{ab}$ \\
\hline 2. SP 803280 & $15,7 \mathrm{ab}$ & $20,9 \mathrm{a}$ & $12,6 \mathrm{a}$ & $33,6 \mathrm{bc}$ \\
\hline 3. RB 855453 & $15,4 \mathrm{abc}$ & $20,4 \mathrm{ab}$ & $12,8 \mathrm{a}$ & $29,7 \mathrm{c}$ \\
\hline 4. SP 801842 & $15,5 \mathrm{ab}$ & $20,8 \mathrm{a}$ & $13,1 \mathrm{a}$ & $29,8 \mathrm{c}$ \\
\hline 5. SP 891115 & $16,0 \mathrm{a}$ & $20,9 \mathrm{a}$ & $12,0 \mathrm{a}$ & 39,0 a \\
\hline 6. RB 867515 & $15,1 \mathrm{abc}$ & $20,3 \mathrm{ab}$ & $12,7 \mathrm{a}$ & 38,6 a \\
\hline 7. PO 8862 & $14,2 \mathrm{c}$ & $18,8 \mathrm{c}$ & $11,7 \mathrm{a}$ & $37,1 \mathrm{ab}$ \\
\hline 8. RB 855156 & $16,0 \mathrm{a}$ & $21,3 \mathrm{a}$ & $12,3 \mathrm{a}$ & $33,7 \mathrm{bc}$ \\
\hline 9. SP 801816 & $15,8 \mathrm{ab}$ & $20,7 \mathrm{a}$ & $12,3 \mathrm{a}$ & $32,8 \mathrm{bc}$ \\
\hline 10. SP 813250 & $14,7 \mathrm{abc}$ & $20,5 \mathrm{ab}$ & $15,0 \mathrm{a}$ & $34,9 \mathrm{ab}$ \\
\hline Valores de F & $5,80 * *$ & $4,40 * *$ & $1,00^{\mathrm{ns}}$ & $6,70 * *$ \\
\hline C.V. $(\%)$ & 6,80 & 6,70 & 33.6 & 14,20 \\
\hline D.M.S. & 1,40 & 1,80 & 5,60 & 6,40 \\
\hline
\end{tabular}

**- Significativo ao nível de $1 \%$ de probabilidade;

ns- Não significativo;

Médias seguidas de mesma letra na coluna, não diferem estatisticamente entre si, pelo teste Tukey ( $\mathrm{P}>0,05)$.

Quanto à produção estimada de açúcar, observa-se que nas condições em que foram conduzidos os ensaios, as variedades de cana-de-açúcar mais produtivas foram: SP 89 1115, RB 867515 e PO 8862 apesar de diferirem somente das variedades SP 803280 , RB 85 5453, SP 80 1842, RB 855156 e SP 801816. 
Tabela 16. Efeito de diferentes herbicidas sobre os teores de pol, brix, fibra e rendimento de açúcar em diferentes variedades de cana-de-açúcar. Botucatu/SP, 2007/08.

\begin{tabular}{|c|c|c|c|c|c|}
\hline \multirow{2}{*}{ Tratamentos } & \multirow{2}{*}{$\begin{array}{c}\text { Dose } \\
\left(\mathrm{g} \mathrm{ha}^{-1}\right) \\
\end{array}$} & \multicolumn{3}{|c|}{ Teor } & \multirow{2}{*}{$\begin{array}{l}\text { Rendimento } \\
\left.\text { açúcar (t ha }{ }^{-1}\right)\end{array}$} \\
\hline & & Pol & Brix & Fibra & \\
\hline topramezone $^{1}$ & 70 & 15,2 & 20,2 & 12,6 & 32,5 \\
\hline topramezone ${ }^{1}+$ tebuthiuron & $70+1000$ & 15,3 & 20,5 & 12,5 & 35,5 \\
\hline topramezone ${ }^{1}+$ tebuthiuron & $100+1000$ & 15,2 & 20,7 & 14,0 & 34,4 \\
\hline ametryn + tebuthiuron & $1500+1000$ & 15,4 & 20,5 & 12,5 & 35,2 \\
\hline testemunha & -- & 15,3 & 20,3 & 12,6 & 33,9 \\
\hline Valores de F & & $0,10^{\mathrm{ns}}$ & $1,50^{\mathrm{ns}}$ & $0,90^{\mathrm{ns}}$ & $1,50^{\mathrm{ns}}$ \\
\hline C.V. $(\%)$ & & 7,40 & 4,10 & 31,10 & 10.90 \\
\hline D.M.S. & & 0,80 & 0,60 & 2,90 & 2,70 \\
\hline
\end{tabular}

A influência dos herbicidas nos teores de pol, brix, fibra e a quantidade de açúcar estimada de cana-de-açúcar estão apresentadas na Tabela 16. Verifica-se que nenhum dos parâmetros tecnológicos analisados foi significativamente afetado pela ação dos herbicidas testados. Veline et al. (2000), Azania (2001) e Terra (2003), estudando seletividade de diferentes herbicidas em variedades de cana-de-açúcar também não observaram efeitos negativos dos herbicidas sobre as características tecnológicas dos colmos das variedades de cana-de-açúcar analisados; o que evidencia, que todos os tratamentos químicos utilizados neste estudo não influenciaram de forma negativa nos parâmetros tecnológicos dos colmos e na produção de açúcar, apesar de alguns tratamentos proporcionarem elevados sintomas iniciais de injúrias, acima de 27\%, valores considerados elevados por Velini et al (1993), no qual consideram que as taxas de injúrias acima de $27 \%$ poderiam comprometer negativamente nos parâmetros quantitativo e qualitativo dos colmos. Provavelmente, em detrimento de não serem os mesmos herbicidas estudados e das condições ambientais favoráveis para o desenvolvimento da cultura. 


\section{CONCLUSÕES}

Todos os herbicidas utilizados foram seletivos para as dez variedades de cana-deaçúcar em condição de cana-planta.

A mistura do tebuthiuron ao herbicida topramezone reduziu os sintomas iniciais de injúrias deste ultimo em todas as variedades estadas;

Nenhum dos herbicidas testados afetou significativamente os componentes tecnológicos das variedades estudadas;

Os parâmetros produtivos das variedades estudadas não foram afetados pelos herbicidas utilizados no estudo; 


\section{REFERÊNCIAS BIBLIOGRÁFICAS}

ANONYMOUS. 2006. Impact Herbicide, technical information and use guide for field corn, sweet corn and popcorn. AMVAC, Los Angeles, Calif.

AREVALO, R.A., TARDIVO, J.C., BERTONCINI, E.I., CAMARGO, P.N.. Herbicidas para Sachcarum spp (cana-de-açúcar) no Brasil. In: CONGRESSO BRASILEIRO DA CIÊNCIA DAS PLANTAS DANINHAS, 21ㅜ, 1997, Caxambu. Anais... Caxambu: SBCPD, 1997. p. 240

AREVALO, R.A.; BERTONCINI, E. I; CASAGRANDE, A.A.; PERESSIN, V.A.. Eficiência dos herbicidas para o manejo das doses principais espécies de plantas daninhas da cana-deaçúcar. In: I FORUM DE HERBICIDAS PARA A CULTURA DA CANA-DE-AÇÚCAR, 1998, Campinas. Documentos IAC - N.63. Campinas, 1998. p. 12 -18 
AZANIA, C.A.M.; CASAGRANDE, A.A; ROLIM, J.C. Seletividade de Imazapic (Saccharum spp). Planta Daninha. Londrina, v.19, n.3, p. 345-350, 2001.

AZANIA, A.A.P.M. et al. Interferência da palha de cana-de-açúcar (Saccharum spp.) na emergência de espécies de plantas daninhas da família convolvulaceae. Planta aninha, Viçosa, v.20, n.2, p.207-212, 2002.

AZANIA, C.A.M. Comparação de métodos para determinar a seletividade de herbicidas na cultura da cana-de-açúcar. 2004, 116f. Tese (Doutorado em Agronomia / Produção 114 Vegetal) - Faculdade de Ciências Agrárias e Veterinárias, Universidade Estadual Paulista, Jaboticabal, 2004.

BARELA, J.F. e CHRISTOFFOLETI, P.J. Seletividade de herbicidas aplicados em préemergencia da cultura da cana-de-açúcar (RB 86 7515) tratada com nematicidas. Planta aninha, Viçosa, v.24, n.2, p.371-378, 2002.

BARROS, A.C.; LEONEL, D.M. Eficácia e seletividade da mistura trifloxysulfuronsodium/ ametryne para o controle de plantas daninhas na cultura da cana-de-açúcar. Revista Brasileira de Herbicidas, v.2, n.3, p.93-106, 2001.

CHRISTOFFOLETI, J.C.; NICOLAI, M.; CARVALHO, S.J.P. Capim-colchão na cana: os danos causados pela infestação do capim-colchão (Digitaria spp.) nos canaviais e as recomendações para controlá-lo. IDEA News, ano 5, n.55, p.30-32, 2005.

CLEMENT A.A.; LAMMEL, J.S.; FILHO J.A.; BARBOSA, J.C. Controle de plantas daninhas em cana-de-açúcar (Saccharum oficinarum) com hexazinone e suas misturas com diuron, em pré-emergência. Planta daninha. Londrina, v. 2, n. 2, p. 85-88, 1979.

CONSECANA. Regulamento dos negócios de compra e venda de cana-de-açúcar no Estado de São Paulo: Manual de Instruções. Piracicaba: 2006. 16p. Apostila. 
COnStAntin, J. Avaliação da Seletividade do Herbicida Halosulfurom à Cana-deaçúcar (Sacarum spp). Botucatu: UNESP, 1996. 71 p. Tese (Doutorado em Agricultura) Faculdade de Ciências Agrárias, Universidade Estadual Paulista, 1996.

CONSTANTIN, J.; CONTIERO, L.R.; ZAGATTO, A. Eficiência e fitotoxicidade do herbicida isouron, comparado com herbicidas tradicionais, na cultura da cana-de-açúcar (Saccharum spp). - cana-planta. Unimar, v. 18, n. 3, p. 477-486, 1996.

CORREIA, N.M.; DURIGAN, J.C. Emergência de plantas daninhas em solo coberto com palha de cana-de-açúcar. Planta Daninha, Viçosa, v.22, n.1, p.11-17, 2004.

CORREA,.R.C. Dinamica e eficiencia da mistura formulada de diuron ehexazinone no sistema de producao de cana-de-acucar. 2006, 150f. Tese (Doutorado em Agronomia / Agricultura) - Faculdade de Ciências Agronômicas, Universidade Estadual Paulista, Botucatu, 2006.

CRUZ, L.S.P.; LEIDERMAN L. Competição entre quatro herbicidas indicados para o controle de plantas daninhas em cana-de-açúcar (Saccharum sp). Planta Daninha. Londrina, v. 1, n. 2, p. $43-48,1978$.

CRUZ, L.S.P.; GURGEL, M.N.A. Efeitos de hexazinone e diuron e suas misturas, no controle de capim-de-colchão (Digitaria sanguinalis L. Scop) em cana-de-açúcar. Planta Daninha. Londrina, v. 6, n. 1, p. 15-20, 1983).

DEUBER, R. Ciências das plantas infestantes - Manejo. ed. do autor, Vol. 2, Campinas 1997, $285 \mathrm{p}$.

DIAS, N.M.P. et al. Absorção e translocação do herbicida diuron por espécies suscetível e tolerante de capim-colchão (Digitaria spp.). Planta Daninha, Viçosa, v.21, n.2, p.293-300, 2003. 
DURIGAN, J.C. Effects of plant densities and management of purple nutsedge on sugarcane yield and effect of growth stages and main way of herbicides contact and absorpsion on the control of tubers. Journal of Environmental Science and Health, B40: 111-117, 2005.

DURIGAN-MARCEL, E.B;.DURIGAN, J.C. and MARTINI, G. Selectivity of the herbicide flazasulfuron applied after postemergence in sugarcane (Saccharum spp. L.) crop Journal of Environmental Science and Health, B40: 177-180, 2005.

EDWARD, P.; RICHARD, JR. Johnsongrass (Sorgum halepense) control in fallow sugarcane (Saccharum spp. Hybrids) fields. Weed Technology, v. 11, p. 410-416, 1997.

EMBRAPA Sistema Brasileiro de Classificacao de Solo. Rio de Janeiro: CNPS. 1999. 412 p.

FAGLIARI, J.R.; OLIVEIRA JR., R.S.; CONSTANTIN J. Métodos de avaliação da seletividade de herbicidas para a cultura da cana-de-açúcar. Acta Scientiarum, n.23, v.5, p.1229-1234, 2001.

FERNANDES, A. C. Cálculos na agroindústria de cana-de-açúcar. Piracicaba: STAB, 2000. p. 66.

F.N.P., Consultoria \& Comércio AGRIANUAL 2008. Anuário da Agricultura Brasileira.. São Paulo: Argros Comunicação, 266 p. 2008

F.N.P., Consultoria \& Comércio, AGRIANUAL 1997. Anuário da agricultura Brasileira. São Paulo: Argros Comunicação, p.241-256, 1997.

FURUHASHI, S.; BRAZ, B.A.; OLIVEIRA, N.A.; HERNANDEZ, D.D. Efeito fitotóxico de flazasulfuron em três cultivares de cana-de-açúcar (Saccharum spp). In: CONGRESSO 
BRASILEIRO DA CIÊNCIA DAS PLANTAS DANINHAS, 22 ${ }^{\circ}, 2000$, Foz do Iguaçu. Anais...Foz do Iguaçu: SBCPD, 2000, p. 314.

GROSSMANN, K. \& EHRHARDT, T. On the mechanism of action and selectivity of the corn herbicide topramezone: a new inibitor of 4-hydroxyphenylpyruvate dioxygenase. Pest Management Science, 63:429-439 (2007).

KUVA, M.A. Efeito de período de controle e de convivência das plantas daninhas na cultura da cana-de-açúcar (Saccharum sp.) no estado de São Paulo. 1999, 74p. Dissertação (Mestrado em Agricultura) - Escola Superior de Agricultura Luiz de Queiroz, Universidade de São Paulo, Piracicaba, 1999.

KUVA, M.A. et al. Períodos de interferência das plantas daninhas na cultura da cana-de açúcar. II - Capim-braquiária (Brachiaria decumbens). Planta Daninha, Viçosa, v.19, n.3, p.323-330, 2001.

KUVA, M.A. et al. Períodos de interferência das plantas daninhas na cultura da canadeaçúcar. III - Capim-braquiária (Brachiaria decumbens) e Capim-colonião (Panicum maximum). Planta Daninha, Viçosa, v.21, n.1, p.37-44, 2003.

LEIBRANDT, N.B. Three new herbicides for use in sugarcane fields in South Africa. In: XXI Congress of the International Society of Sugar Cane Technologies Bangkok 1995. p. 11-20. Agris 1999 - 2002.

LORENZI, J.H.; NETO, V.B.; OLIVEIRA, J.E. Estudo do efeito do herbicida oxifluorfen, aplicado em pré-emergência, sobre o crescimento e produtividade da cana-de-açúcar (Saccharum officinarum) cv. SP 71 6163. STAB, v. 12, n.4, p. 24-26, 1994.

LORENZI, H. Plantas daninhas na cultura da cana-de-açúcar: Plantas daninhas na lavoura do nordeste brasileiro. In: ENCONTRO TÉCNICO GOAL, CANA-DE-AÇÚCAR, 4., 1995, Recife. Anais... Recife: 1995. 
LORENZI, H. Plantas daninhas e seu controle na cultura da cana-de-açúcar. In: SEMINÁRIO DE TECNOlOGIA AGRONÔMICA, 4., 1988, Piracicaba. Anais... São Paulo: COOPERSUCAR, 1988. p. 281-301.

MACIEL, C.D.G., VELINI, E.D., CONSTANTIN, J., JARDIM, C.E., BARNARDO, R.S., FONSECA, P.P.M., BAREJA, J.D. e OLIVEIRA, J.S. Eficiência e seletividade dos herbicidas trifloxysulfuron-sodium + ametrine e hexazinone + diuron em função da tecnologia de aplicação e do manejo mecânico da palha de cana-de-açúcar na linha de plantio. . Planta Daninha, Vicosa-MG, v.26, n.3, p.665-676, 2008.

MARTINS, D. et al. Emergência em campo de dicotiledôneas infestantes em solo coberto com palha de cana-de-açúcar. Planta Daninha, Botucatu, v.17, n.1, p.151-161, 1999.

MASCARENHAS, M.H.T.; GALLI, A.J.B.; VIANA, M.C.M.; MACEDO, G.A.R.; LARA, J.F.R. Eficiência do halosulfuron no controle de tiririca (Cyperus rotundus) na cultura da canade-açúcar. Planta daninha. Londrina, v. 13, n. 2, p. 69-80, 1995.

MASON, G.F. The response of plant cane of different varieties to different pre-emerencies herbicidal treatments. In: West Indies Sugar Technologists Conference. Kingston 1991. p. 112-124. Agris 1991 - 1992.

MILLHOLLON, R.W.; FANGUY, H.P. Growth response of six sugarcane cultivars to the herbicides asulam, dalapon and MSMA. Journal - American-Society-of-Sugar-CaneTechnologists. 1989. Cab Abstracts 1991 - 1992.

MILLHOLLON, R.W.; BENDA, G.T.A. Effect of herbicides metribuzin and terbacil and seed cane treatments of sugarcane development and yield. Sugar-Cane. 1999, No. 2, p. 4-10, Houma, 1999. Agris 1998 - 2000. 
NEGRISOLI, E. Seletividade de Herbicidas Aplicados em Pré-Emergência e Associados a Nematicidas, à Cultura da Cana-de-açúcar, Cultivar RB 85 5113. Botucatu: UNESP, 2002. 48 p. Dissertação (Mestrado em Agricultura) - Faculdade de Ciências Agrárias, Universidade Estadual Paulista, 1999.

OLIVEIRA, A.R \& FREITAS, S.P. Levantamento fitossociologico de plantas daninhas am áreas de produção de cana-de-açúcar. Planta Daninha, Vicosa-MG, v.26, n.1, p.33-46, 2008.

OliveIRA, JR., R.B.; CONSTANTIN, J. Plantas Daninhas e seu Manejo. Guaíba: Agropecuária, 2001. 362 p.

PEDRINHO JR., A.F.F.; MARTINI, G.; DURIGAM, J.C. Controle de tiririca (Cyperus rotundus) na cultura da cana-de-açúcar com imazapyr isolado ou em mistura com pendimentalin. Revista Brasileira de Herbicidas, Brasília, DF, v. 2, n. 1², p. 23 -29, 2001.

PEDRINHO JR., A.F.F; DURIGAM, J.C. Controle de Capim-colonião na cultura da cana-deaçúcar com herbicidas aplicados em pré-emergência. Revista Brasileira de Herbcidas, Brasília, DF, v. 2, n. 3, p. 23-29, 2001.

PITELLI, R.A. Interferência das plantas daninhas em culturas agrícolas. Informe Agropecuário, v. 11, n. 129, p. 16-27, 1985.

PROCÓPIO, S.O. et al. Manejo de plantas daninhas na cultura da cana-de-açúcar. Viçosa: Universidade Federal de Viçosa, 2003. 150p.

PROCÓPIO, S. O.; SILVA, A. A.; VARGAS, L. Manejo e controle de plantas daninhas em cana-de-açúcar. In: VARGAS, L.; ROMAN, E. S. (Eds.). Manual de manejo e controle de plantas daninhas. Bento Gonçalves: Embrapa Uva e Vinho, 2004. p. 397-452.

RODRIGUES, B.N.; ALMEIDA, F.S. Guia de herbicidas: contribuição para o uso adequado em plantio direto e convencional. 4. ed. Londrina, IAPAR, 1998. p. 361-365. 
RAMALHO, J.F.G.P.; GRACIANO, P.A. Efeito de Amertyne em quatro variedades de canade-açúcar (Saccharum spp).STAB, v. 1, n. 3, p. 24-25, 1983.

ROLIM, J.C.; CHRISTOFFOLETI, P.J. Tolerância de variedades de cana-de-açúcar ao herbicida tebuthiuron. STAB, v. 2, n. 4, p. 20-24, 1984.

ROLIM, J.C; JANEGETZ, I; GARMS, M.A. Tolerância de variedades de cana planta à herbicidas. 1 - cana planta, solo arenoso, em pré-emergência. In: CONGRESSO BRASILEIRO DA CIÊNCIA DAS PLANTAS DANINHAS, 22 ${ }^{\circ}, 2000$, Foz do Iguaçu. Anais...Foz do Iguaçu: SBCPD. 2000. p. 294.

SILVA, A.A.; FERREIRA, F.A.; SILVA, J.F.; OLIVEIRA, M.F. Tolerância da cana-deaçúcar (Saccharum spp) ao flazasulfuron em aplicações isoladas, seqüenciais e em misturas com outros herbicidas e seus efeitos sobre a tiririca (Cyperus rotundus L.) e ouras espécies de plantas daninhas. Ceres, v. 43, n. 245, p. 102-11, 1996.

TERRA, M.A.; Seletividade de diclosulam, trifloxysulfuron-sodium e ametryne a variedades de cana-de-açúcar. 2003. 60 f. Dissertação (Mestrado em Agricultura) Universidade Estadual Paulista, Botucatu, SP, 2003.

VARGAS, L; FLECK, N.G. Seletividade de herbicidas do grupo químico das ariloxifenoxipropionatos a cereais de inverno. Planta Daninha. Londrina, v. 17, n. 1, p. 41$51,1999$.

VELINI, E.D.; FREDERICO, L.A., MORELLI, J.L.; MARUBAYASHI, O.M. Avaliação dos efeitos de doses do herbicida clomazone, aplicado em pós-emergência inicial, sobre o crescimento e produtividade de soqueira de cana-de-açúcar (Saccharum officinarum C.v. SP 71-1406). STAB, v. 12, n. 2, p. 31-35, 1993. 
VELINI, E.D.; MARTINS, D. Efeito da palha da cana-de-açúcar sobre a germinação das principais espécies de plantas daninhas desta cultura. Relatório Técnico, Botucatu: Faculdade de Ciências Agronômicas / UNESP, 1998. 26p.

VELINI, E.D.; MARTINS, D.; MANOEL, L.A.; MATSUOKA, S.; TRAVAIN, J.C.; CARVALHO, J.C. Avaliação da seletividade da mistura de oxyfluorfen e ametryne, aplicada em pré ou pós-emergência, a dez variedades de cana-de-açúcar (cana-planta). Planta Daninha. Londrina, v. 18, n. 1, p. 123-134, 2000. 